\title{
More milk from forage: Milk production, blood metabolites, and forage intake of dairy cows grazing pasture mixtures and spatially adjacent monocultures
}

\author{
Keith G. Pembleton, ${ }^{11,2}$ James L. Hills, ${ }^{*}$ Mark J. Freeman, ${ }^{*}$ David K. McLaren, ${ }^{*}$ Marion French, $\dagger^{3}$ \\ and Richard P. Rawnsley* \\ *Tasmanian Institute of Agriculture, University of Tasmania, Private Bag 3523, Burnie TAS 7320, Australia \\ †School of Land and Food, University of Tasmania, Private Bag 78, Hobart TAS 7001, Australia
}

\begin{abstract}
There is interest in the reincorporation of legumes and forbs into pasture-based dairy production systems as a means of increasing milk production through addressing the nutritive value limitations of grass pastures. The experiments reported in this paper were undertaken to evaluate milk production, blood metabolite concentrations, and forage intake levels of cows grazing either pasture mixtures or spatially adjacent monocultures containing perennial ryegrass (Lolium perenne), white clover (Trifolium repens), and plantain (Plantago lanceolata) compared with cows grazing monocultures of perennial ryegrass. Four replicate herds, each containing 4 spring-calving, cross-bred dairy cows, grazed 4 different forage treatments over the periods of early, mid, and late lactation. Forage treatments were perennial ryegrass monoculture (PRG), a mixture of white clover and plantain (CPM), a mixture of perennial ryegrass, white clover, and plantain (RCPM), and spatially adjacent monocultures (SAM) of perennial ryegrass, white clover, and plantain. Milk volume, milk composition, blood fatty acids, blood $\beta$-hydroxybutyrate, blood urea $\mathrm{N}$ concentrations, live weight change, and estimated forage intake were monitored over a 5-d response period occurring after acclimation to each of the forage treatments. The acclimation period for the early, mid, and late lactation experiments were 13,13 , and 10 d, respectively. Milk yield (volume and milk protein) increased for cows grazing the RCPM and SAM in the early lactation experiment compared with cows grazing the PRG, whereas in the mid lactation experiment, milk
\end{abstract}

\footnotetext{
Received October 19, 2015.

Accepted January 12, 2016

${ }^{1}$ Corresponding author: Keith.Pembleton@usq.edu.au

${ }^{2}$ Present address: Institute for Agriculture and the Environment, University of Southern Queensland, Toowoomba, QLD, 4350, Australia.

${ }^{3}$ Present address: Murray Goulburn, Bundalaguah Road, Maffra VIC 3860, Australia.
}

fat increased for the cows grazing the RCPM and SAM when compared with the PRG treatments. Improvements in milk production from grazing the RCPM and SAM treatments are attributed to improved nutritive value (particularly lower neutral detergent fiber concentrations) and a potential increase in forage intake. Pasture mixtures or SAM containing plantain and white clover could be a strategy for alleviating the nutritive limitations of perennial ryegrass monocultures, leading to an increase in milk production for spring calving dairy cows during early and mid lactation.

Key words: pasture-based dairy systems, species mixtures, monocultures, forage intake, novel forage species

\section{INTRODUCTION}

Perennial ryegrass (Lolium perenne) is the major pasture species grown on dairy farms in the southern dairy regions of Australia and in New Zealand (Doyle et al., 2000; Holmes, 2007). Ryegrass is highly productive, has efficient responses to irrigation (Rawnsley et al., 2009) and $\mathrm{N}$ inputs (Pembleton et al., 2013), and is easy to establish and manage. However, $70 \%$ of annual growth occurs during spring (Rawnsley et al., 2007), which is associated with the transition from high-nutritive value vegetative growth to low-nutritive value reproductive development. The resulting oversupply of lowernutritive value forage in spring presents a management challenge to producers. Management options currently employed to address this include conserving excess forage as silage, pre- or postgrazing topping (mechanical mowing) to achieve the desired postgrazing residual, or forcing cows to graze to the desired residual (Irvine et al., 2010). Whereas all of these options are considered appropriate management strategies, they limit efficient conversion of forage to milk, through either reduced forage intakes, reduced forage nutritive values, or increased wastage levels during forage conservation and feeding.

The inclusion of nongrass pasture species within the forage base may provide a complementary forage op- 
tion that improves overall pasture nutritive value and helps alleviate the spring surplus by pushing growth into the pre- and postspring periods. Although legumes have long been recognized as important components of pastoral systems (Penning et al., 1995; Frame and Laidlaw, 2005), the increased use of $\mathrm{N}$ fertilizer to improve pasture productivity has led to a botanical composition shift from a legume grass mixture to a grass monoculture (Feyter et al., 1985; Bolland and Guthridge, 2007).

Forbs have long been considered important components of pasture (Foster, 1988), providing benefits of improved mineral nutrition (Stewart, 1996; PirhoferWalzl et al., 2011) and overall nutritive value (Woodward et al., 2008) of forage during periods when ryegrass growth rates are low. However, many dairy pastures' contain little or no forb component. The development of improved cultivars of the forbs plantain (Plantago lanceolata) and chicory (Cichorium intybus) coupled with increasing environmental concerns, in regard to high levels of $\mathrm{N}$ fertilizer inputs into pastoral systems in general, has renewed interest in the forb and legume components of pastures. This interest centers on reduced $\mathrm{N}$ fertilizer requirements (Frame et al., 1998; Brown et al., 2005; Labreveux et al., 2006) and improved stress tolerance of forbs when compared with perennial ryegrass (Stewart, 1996; Neal et al., 2011). Campling (1984), Thomson et al. (1985), and Derrick et al. (1993) have demonstrated increased voluntary intake in dairy cows grazing forbs, whereas Conrad et al. (1982) , Kusmartono et al. (1996), Barry (1998), Harris et al. (1998), Woodward et al. (2008), and Sun et al. (2012) demonstrated their potential to increase animal production.

Several approaches exist to incorporate forb and legume species into dairy pastures without sacrificing the ease of management and input responsiveness that make ryegrass so favored. These include forage mixtures of legumes and forbs, with or without a grass component, or spatially adjacent monocultures. Whereas mixtures present an opportunity for each species to exploit suitable niches within the pasture (Sanderson et al., 2005; Picasso et al., 2011), maximizing complementary aspects of the species, they do present limited herbicide options and careful management of grazing pressure and $\mathrm{N}$ inputs that are required to maintain the desired botanical composition. Spatially adjacent monocultures, where each species is sown as a monoculture within the boundaries of the same field, offer the opportunity to manage each species' individual requirements. Experimental evidence from rotationally grazed dairy sheep suggests spatially adjacent monocultures of annual ryegrass (Lolium multiflorum) and sulla (Hedysarum coronarium) can improve animal production above that of grass monocultures (Molle et al., 2007). Similarly, spatially adjacent monocultures of perennial ryegrass and white clover improved animal performance compared with mixtures of the 2 species (Champion et al., 2004), as they allow animals to efficiently select a diet higher in legumes (Rook et al., 2002). As yet, no evaluation of forbs as a component of spatially adjacent monocultures in livestock production systems has occurred.

The aim of our experiments was to determine if species mixtures or spatially adjacent monocultures are able to increase milk production of pasture-based dairy systems. Over the states of lactation (early, mid, and late lactation), milk production, key blood metabolites, and forage intake of dairy cows grazing mixtures containing perennial ryegrass, white clover, and plantain or spatially adjacent monocultures were evaluated in comparison to perennial ryegrass monocultures.

\section{MATERIALS AND METHODS}

\section{Site Description}

The experiments were done at the Tasmanian Dairy Research Facility at Elliott, Tasmania, Australia $\left(41^{\prime} 08^{\prime \prime} \mathrm{S}, 145^{\prime} 77^{\prime \prime} \mathrm{E}\right)$. This location has a mean daily maximum temperature of $15^{\circ} \mathrm{C}$, a mean daily minimum temperature of $7^{\circ} \mathrm{C}$, and an annual total rainfall of 1,200 mm (65\% distributed between May and October, inclusive). The soil is classified as a clay loam red ferrosol soil (Soil Survey Staff, 1990; Isbell, 2002).

\section{Experimental Design}

The experimental design, treatments, and all animal procedures were approved by the University of Tasmania's Animal Ethics committee (Approval A0012629). Three experiments were undertaken, covering mid (January 2013), late (May 2013), and early lactation (September/October 2013). In each experiment, 4 replicate herds of 4 lactating spring-calving, cross-bred dairy cows were grazed continuously on 4 forage treatments (a total of 64 cows). Each herd was balanced for age, milk production, DIM, and live weight (Table 1). The forage treatments were a monoculture of perennial ryegrass (cultivar 'Base'; PRG); a mixture of perennial ryegrass ('Base'), white clover ('Kopu II'), and plantain ('Tonic'; RCPM); a mixture of white clover ('Kopu II') and plantain ('Tonic'; CPM); and spatially adjacent monocultures (SAM) of perennial ryegrass ('Base'), white clover ('Kopu II'), and plantain ('Tonic'; Figure $1)$. Cows were offered an equal area of each species monoculture. 


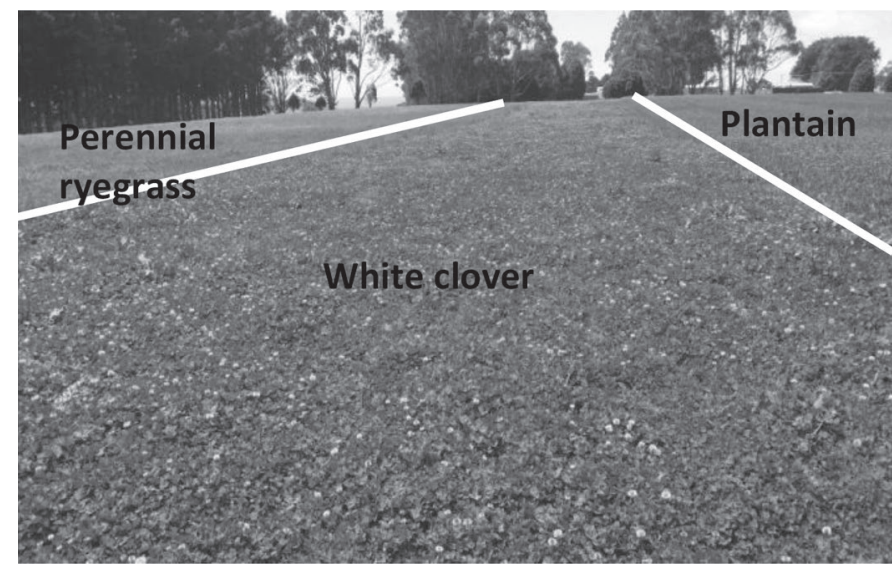

Figure 1. Arrangement of monocultures of perennial ryegrass, white clover, and plantain as spatially adjacent monocultures within a field.

\section{Agronomic Management of Forage Treatments}

Ten experimental areas (5 irrigated and 5 dryland) were sown to each of the 4 forage treatments between April 18 and 26, 2012. Experimental areas ranged between 2 and 4 ha in size. All forage treatments were sown into fully prepared seedbeds. During seedbed preparation, P (in the form of triple super phosphate), $\mathrm{K}$ (in the form of muriate of potash), and lime were applied at rates to achieve a target soil Olsen $\mathrm{P}$ level of $20 \mathrm{mg} / \mathrm{kg}$, a soil Colwell $\mathrm{K}$ level of $250 \mathrm{mg} / \mathrm{kg}$, and a soil $\mathrm{pH}$ of at least $5.5\left(\mathrm{H}_{2} \mathrm{O}\right)$. Sowing rates were based on local agronomist advice to achieve stable mixtures of each desired species, and these were $25 \mathrm{~kg}$ of seed/ ha for the PRG treatment and the perennial ryegrass component of the SAM; $4 \mathrm{~kg}$ of seed/ha for the white clover monoculture component of the SAM; $10 \mathrm{~kg}$ of seed/ha for the plantain component of the SAM; $20 \mathrm{~kg}$ of perennial ryegrass seed, $2 \mathrm{~kg}$ of white clover seed, and $1 \mathrm{~kg}$ of plantain seed/ha for the RCPM; and $4 \mathrm{~kg}$ of plantain seed and $2 \mathrm{~kg}$ of white clover seed/ha for the CPM. All experimental areas were sown with a Duncan Renovator MKIII seed drill (Duncan Ag, Melbourne, Australia) with 150-mm row spacing.

Experimental areas were allowed to establish during the 2012 autumn and winter (May, June, July, and
August), with the first grazing of each area occurring between August 28 and September 18, 2012. Subsequent grazings were timed to coincide with the perennial ryegrass leaf regrowth stage of between 2.5 and 3 leaves, except during spring, when grazing coincided with perennial ryegrass regrowth of between 2 and 2.5 leaves. Cows remained grazing in each experimental area until the perennial ryegrass had a residual biomass between 1,100 and 1,400 $\mathrm{kg}$ of DM/ha. Grazing was undertaken using either lactating or dry dairy cows.

Phosphorus and K fertilizer were applied on April 16, 2013 , in the form of single super phosphate, triple super phosphate, and muriate of potash at rates of $80 \mathrm{~kg}$ of $\mathrm{P}$, $50 \mathrm{~kg}$ of $\mathrm{K}$, and $18 \mathrm{~kg}$ of S/ha. Nitrogen fertilizer was applied 3 times to each experimental area. Each application consisted of $40 \mathrm{~kg}$ of $\mathrm{N} / \mathrm{ha}$ applied in the form of urea and occurred between $2 \mathrm{~d}$ prior to grazing and $10 \mathrm{~d}$ after grazing of each area. Applications occurred during the months of December in 2012 and April and August in 2013.

The presence of volunteer species (Onopordum acanthium, Arctotheca calendula, Rumex spp., Dactylis glomerata, and Poa annua) within each forage treatment was minimized through the use of selective herbicides. Dicot species in the PRG forage treatment and the perennial ryegrass monoculture component of the SAM were targeted using MCPA (750 g/L, Agritone 750, Nufarm Australia Ltd., Melbourne, Australia) at a rate of $1 \mathrm{~L} / \mathrm{ha}$ and Dicamba (500 g/L, Kamba 500, Nufarm Australia Ltd.) at a rate of $280 \mathrm{~mL} / \mathrm{ha}$. Monocots within the CPM forage treatment and the clover and plantain monoculture component of the SAM were targeted using Fluazifop-p (128 g/L, Fusilade forte, Syngenta Australia Pty. Ltd., Sydney, Australia) at 820 $\mathrm{mL} /$ ha in 2012 and Haloxyfop (520 g/L, Verdict 520, Dow Agrosciences Australia Ltd., Sydney, Australia) at $100 \mathrm{~mL} /$ ha in 2013. Broadleaf weeds in the CPM and RCPM forage treatments were targeted using Terbutryn (500 g/L, Igran 500, Crop Care Australasia, Brisbane, Australia) at $400 \mathrm{~mL} / \mathrm{ha}$ in combination with spot spraying, using Dicamba or MCPA/Diflufenican (250 and 25 g/L, Tigrex, Bayer Crop Science Pty. Ltd., Melbourne, Australia) for heavy infestations. Broad applications of herbicides occurred between June and

Table 1. The average $( \pm \mathrm{SD})$ age, DIM, live weight, and milk production of the cows used in each of the experiments

\begin{tabular}{lccc}
\hline Item & $\begin{array}{c}\text { Mid lactation } \\
\text { (January 2013) }\end{array}$ & $\begin{array}{c}\text { Late lactation } \\
\text { (May 2013) }\end{array}$ & $\begin{array}{c}\text { Early lactation } \\
\text { (September/October 2013) }\end{array}$ \\
\hline Age (yr) & $4.04 \pm 1.77$ & $4.51 \pm 1.79$ & $3.31 \pm 2.02$ \\
DIM & $125 \pm 22$ & $246 \pm 23$ & $35 \pm 8$ \\
Live weight (kg) & $531 \pm 54$ & $555 \pm 57$ & $430 \pm 57$ \\
Milk production (L/cow per day) & $20.0 \pm 3.0$ & $13.7 \pm 2.4$ & $20.4 \pm 2.0$ \\
\hline
\end{tabular}


August each year, whereas spot spraying occurred as required.

Irrigated experimental areas received applications of irrigation water between November 1, 2012, and April 1, 2013. Water was applied through pressurized sprinkler systems. Applications were timed to coincide with a soil water deficit of $25 \mathrm{~mm}$ (estimated from evapotranspiration), and enough water was applied to return the soil profile to field capacity. A total of $320 \mathrm{~mm}$ of irrigation water was applied.

\section{Experimental Procedures and Measurements}

Forage allocation and targeted postgrazing residuals reflected the postgrazing residuals of the farm in the lead up to each experiment. During the early and mid lactation experiments, each cow was offered a daily allowance of $20 \mathrm{~kg}$ of DM of forage above a postgrazing residual of $1,400 \mathrm{~kg}$ of $\mathrm{DM} /$ ha for the $\mathrm{PRG}$, RCPM, and the perennial ryegrass monoculture in the SAM, $1,000 \mathrm{~kg}$ of $\mathrm{DM} / \mathrm{ha}$ for the CPM and plantain monoculture in the SAM, and $600 \mathrm{~kg}$ of $\mathrm{DM} /$ ha for the white clover monoculture in the SAM. During the late lactation experiment, each cow was offered a daily allowance of $20 \mathrm{~kg}$ of DM of forage above a postgrazing residual height of 1,100 kg of DM/ha for the PRG, RCPM, and the perennial ryegrass monoculture in the SAM, 600 $\mathrm{kg}$ of $\mathrm{DM} / \mathrm{ha}$ for the $\mathrm{CPM}$ and plantain monoculture in the SAM, and $300 \mathrm{~kg}$ of $\mathrm{DM} /$ ha for the white clover monoculture in the SAM.

All cows received $3.5 \mathrm{~kg}$ of $\mathrm{DM} / \mathrm{d}$ of grain concentrate (wheat-based pellet with additional mineral and vitamin supplements) during the mid lactation experiment, $4.0 \mathrm{~kg}$ of $\mathrm{DM} / \mathrm{d}$ during the late lactation experiment, and $2.0 \mathrm{~kg}$ of $\mathrm{DM} / \mathrm{d}$ during the early lactation experiment. Supplementary concentrates were fed in the dairy during both morning and evening milking. To reduce the risk of bloat, each cow received monensin from a slow release rumen capsule $(0.32 \mathrm{~g} / \mathrm{d}$; Rumensin, Elanco, Eli Lilly Australia Pty. Ltd., West Ryde, NSW, Australia) administered before the experiment commencing. Furthermore, during the late and early lactation experiments, the white clover monoculture component of the SAM treatment and the CPM treatment was sprayed with an emulsifiable anti-bloat oil (BP Pasture spray, BP Australia Pty Ltd., Melbourne, Australia) immediately before grazing at a rate of 15 L/ha. All cows had ad libitum access to fresh water while grazing the forage treatments.

In the mid and early lactation experiments cows grazed the forage treatments for $18 \mathrm{~d}$, and in the late lactation experiment the cows grazed forage treatments for $15 \mathrm{~d}$. Before each experiment the cows grazed a predominantly perennial ryegrass pasture and were supple- mented with the same wheat-based pellet as used in the experiments. For the first $5 \mathrm{~d}$ of the mid lactation experiment and first $6 \mathrm{~d}$ of the late and early lactation experiments cows grazed dryland experimental areas exclusively. For the remaining duration of each experiment the cows exclusively grazed irrigated experimental areas. Animal measurements were done for the last $5 \mathrm{~d}$ of each experiment (from here on referred to as the response period) once cows were fully adapted to the different forage treatments. To ascertain pre-experimental values for all animal parameters, measurements were also undertaken over the $3 \mathrm{~d}$ before the commencement of each experiment.

Cows were milked twice daily (0700 and $1500 \mathrm{~h}$ ) in their treatment groups. After milking they were returned to the experimental area, drafted into their replicate herds, and placed on their allocated forage areas. A fresh allocation of forage was provided after each milking. Forage areas were measured before grazing to achieve the desired forage allowance per cow, and forage mass was estimated using a rising plate meter (Farmworks Systems, Feilding, New Zealand) calibrated for each experiment and to the specific forage being grazed (Supplemental Table S1; http://dx.doi. org/10.3168/jds.2015-10542). Each herd was contained in their respective allocated forage area through the use of temporary electric fences.

Milk yield of each cow, at each milking, was monitored using a DeLaval Alpro milk metering system (DeLaval International AB, Tumba, Sweden). Milk composition samples were collected at both the morning and afternoon milking on d 2 to 5 of the response period during each experiment and as well as 1 or $2 \mathrm{~d}$ before the beginning of the experiment. Milk samples were assayed for milk fat, milk protein, and lactose concentration using a Bentley B2000 Infrared Milk Analyzer (Bentley Instruments Inc., Chaska, MN) by TasHerd Pty Ltd. (Haspen, Tasmania, Australia). Cow live weight was measured twice daily as cows exited the dairy using automatic in race walk over scales (DeLaval AWS100 automatic weighing system). Blood samples were collected via coccygeal venipuncture using $10-\mathrm{mL}$ Vacutainers (Becton, Dickinson and Company, Plymouth, UK) containing sodium heparin from each cow after the morning milking of $\mathrm{d} 2$ and 5 of the response period in each experiment, as well as immediately before the commencement of each experiment. The collected blood was centrifuged $(1,125 \times \mathrm{g})$ for $10 \mathrm{~min}$ at $4^{\circ} \mathrm{C}$ and the plasma was collected and frozen until laboratory analysis. Plasma was analyzed for BUN, fatty acids, and BHB by the Western Australian Department of Agriculture and Food Animal Health Laboratory (South Perth, Western Australia, Australia) using an Olympus AU400 Chemistry Analyzer (Olympus, Tokyo, Japan). 
Pre- and postgrazing forage mass was determined for each forage allocation on every day of the experiment using a calibrated rising plate meter. Forage intake from each grazing was estimated from the pre- and postgrazing biomass assessments using the following equation:

$$
\text { Estimated forage intake }=\left(\mathrm{M}_{\text {pre }}-\mathrm{M}_{\text {post }}\right) / 4 \text {, }
$$

where $\mathrm{M}_{\text {pre }}=$ pasture mass pregrazing and $\mathrm{M}_{\text {post }}=$ pasture mass postgrazing. Daily estimated forage intake was the sum of the estimated forage intake from the morning and evening grazings. In addition to pre- and postplate meter readings, forage intakes were also calculated using forage nutritive value and energy requirements for maintenance, live weight change, pregnancy, and production from the equations described in CSIRO (2007).

For each forage area, in each field the pregrazing botanical composition was determined by cutting 20 samples of forage to a height of $30 \mathrm{~mm}$ across a transect in each forage area. The sampled material was handseparated into individual botanical components (perennial ryegrass, white clover, plantain, and other volunteer species) and then dried at $60^{\circ} \mathrm{C}$ for $72 \mathrm{~h}$. Each botanical component was weighed and the botanical composition calculated. Following weighing, the samples were milled through a 1-mm screen and assayed for nutritive values. On $3 \mathrm{~d}$ during the response period ( $\mathrm{d} 2,4$, and 5) of each experiment, forage samples were collected, as described above, from each experimental herd's forage allocation immediately before and immediately after grazing. These samples were also hand-separated into the botanical components, dried, and weighed for botanical composition determination before being milled through a 1-mm screen for nutritive value analysis.

All nutritive value samples, along with a sample of the dairy pellet used in each experiment, were analyzed via wet chemistry procedures for $\mathrm{CP}, \mathrm{NDF}, \mathrm{ADF}$, neutral detergent insoluble $\mathrm{CP}$, lignin, ash, water-soluble carbohydrates, starch, fat, and mineral contents along with in vitro dry matter digestibility (IVDMD) and NDF digestibility by the Dairy One Forage Laboratory (Ithaca, NY). Crude protein was determined by multiplying the nitrogen concentration (determined via Kjeldahl digestion followed by titration; Thiex et al., 2002 ) by 6.25 . Fiber fractions (NDF and ADF) were determined using the methods outlined in van Soest et al. (1991) and AOAC (1990). Neutral detergent insoluble $\mathrm{CP}$ was determined by performing a $\mathrm{CP}$ determination on the residue remaining after a NDF determination. Lignin content was determined in Ankom Daisy incubator (Ankom Technologies, Macedon, NY) using the reagents described in AOAC International
(1997). Ash content was determined by the method described in AOAC International (2005). Water-soluble carbohydrates were determined as described by Hall et al. (1999). After the sugar extraction, the residue was thermally solubilized and then incubated with glucoamylase. The concentration of the resulting dextrose was determined using an YSI 2700 Select biochemistry analyzer (YSI Inc. Life Sciences, Yellow Springs, OH). Starch concentration was determined by multiplying dextrose concentration by 0.9 . Fat content was determined after ether extraction, as described in Thiex et al. (2003). The IVDMD and NDF digestibility was determined by incubating samples in a rumen fluid-buffer mixture (as described by Goering and Van Soest, 1970) for $24 \mathrm{~h}$ followed by an NDF extraction using the NDF procedure described above. Mineral concentrations were determined after a 30-min microwave digestion $(1,600$ $\mathrm{W}$ and $200^{\circ} \mathrm{C}$ ) of $1 \mathrm{~g}$ of tissue with $8 \mathrm{~mL}$ of concentrated nitric acid and $2 \mathrm{~mL}$ of concentrated hydrochloric acid in a microwave-accelerated reaction system with MARSXpress temperature control in Xpress Teflon PFA vessels with Kevlar insulating sleeves (CEM, Matthews, NC). After digestion, the mineral concentrations of $\mathrm{Ca}, \mathrm{P}, \mathrm{Mg}, \mathrm{K}, \mathrm{Na}, \mathrm{Fe}, \mathrm{Zn}, \mathrm{Cu}, \mathrm{Mn}$, and $\mathrm{Mo}$ in the solution were determined using an inductively coupled plasma radial spectrometer (Thermo IRIS Advantage HX; Thermo Scientific, Waltham, MA).

Estimated ME was calculated from IVDMD and ether extracted fat (EE) using the equations described in (CSIRO, 2007). For the forages, the estimated ME was calculated using the following equation:

$$
\text { Estimated } \mathrm{ME}=0.194 \mathrm{DOMD}-2.577 \text {, }
$$

where DOMD (dry organic matter digestibility) $=0.84$ IVDMD + 7.32. For the dairy pellet, the estimated ME was calculated using the following equation:

$$
\text { Estimated } \mathrm{ME}=0.138 \mathrm{DOMD}+0.272 \mathrm{EE}+0.86 \text {, }
$$

where DOMD $=0.961$ IVDMD +2.109 . Selection differentials for botanical components and nutritive values were calculated using the following equation, as described in Jacobs et al. (1999):

$$
\text { Selection differential }=\mathrm{N}_{\mathrm{sel}} / \mathrm{N}_{\text {pre }} \text {, }
$$

where $\mathrm{N}_{\text {sel }}=\left[\left(\mathrm{M}_{\text {pre }} \times \mathrm{N}_{\text {pre }}\right)-\left(\mathrm{M}_{\text {post }} \times \mathrm{N}_{\text {post }}\right)\right] /\left(\mathrm{M}_{\text {pre }}\right.$ $-\mathrm{M}_{\text {post }}$ ), where $\mathrm{M}_{\text {pre }}=$ pasture mass pregrazing, $\mathrm{M}_{\text {post }}$ = pasture mass postgrazing, $\mathrm{N}_{\text {pre }}=$ pregrazing concentration of nutrients or species component, and $\mathrm{N}_{\text {post }}=$ postgrazing concentration of nutrients or species component. During each experiment, the environmental 
conditions (temperature, relative humidity, and rainfall) at the site were monitored using an automated weather station (Davis Instrument Corp., Hayward, CA).

\section{Statistical Analysis}

The effect of forage treatment on milk production, milk composition, blood metabolite levels, live weight, live weight change, pre- and postgrazing biomass, and estimated DMI was determined using a REML analysis in Genstat 16.1 (VSN International, Hemel Hempstead, UK). Herd was the replicate in the analysis, forage treatment was a fixed factor, and day of the experiment was included as a random factor. Unless otherwise stated, significant effects or differences were accepted when $P<0.05$.

\section{RESULTS}

\section{Environmental Conditions}

The mid lactation experiment was the warmest of the 3 experiments (Table 2). Daily maximum and minimum temperatures in the late and early lactation experiments were similar. The early lactation experiment was the wettest, with the most rainfall received and the greatest number of rain days. Compared with long-term averages, the period in which the mid lactation experiment was undertaken was drier, whereas the early lactation experiment received considerably more rainfall.

\section{Nutritive Value of Forage Offered}

The diversity in the forage mixtures and species dominance of the monocultures reflected each of the treatments offered to the cows (Table 3). However, a sizable weed component was present in the plantain and clover monoculture components of the SAM treatment (ranging from 1 to 36\%). Overall, greater diversity existed in the irrigated forage mixtures, and the botanical composition of the monocultures was closer to the target composition in the irrigated forage areas when compared with dryland forage areas.

An analysis of the nutritive content of the forage treatments offered (Table 4) revealed the CP levels of the PRG, RCPM, and perennial ryegrass component of the SAM treatments during the mid lactation experiment were low (ranging from 12.7 to $22.6 \%$ ). In this experiment, the NDF levels of the CPM treatment and plantain component of the SAM were lower than the treatments containing ryegrass. However, the ADF concentration of the CPM and plantain component of the SAM was higher. The higher ADF concentration is also reflected in the lower IVDMD and ME content of these treatments. This was also evident in the late and early lactation experiments. Over all 3 experiments, the white clover component of the SAM contained the lowest fiber (NDF, ADF) concentrations and the highest IVDMD and ME content. The full chemical analysis of each forage treatment from each experiment is presented in Supplemental Table S2 (http://dx.doi. org/10.3168/jds.2015-10542).

\section{Milk Production Response}

We noted a significant effect of forage treatment on milk production in each of the 3 experiments. In the mid lactation experiment, the cows grazing the RCPM produced more milk compared with cows grazing the CPM treatment (Figure 2). In the late lactation experiment, cows grazing PRG, SAM, and RCPM treatments had greater milk volumes (L/cow per day) than cows grazing the CPM. In the early lactation experiment,

Table 2. The environmental conditions at the experimental location (Elliott, Tasmania, Australia) during each of the experiments ${ }^{1}$

\begin{tabular}{lccc}
\hline Experiment & $\begin{array}{c}\text { Mid lactation } \\
\text { January 2013) }\end{array}$ & $\begin{array}{c}\text { Late lactation } \\
\text { (May 2013) }\end{array}$ & $\begin{array}{c}\text { Early lactation } \\
\text { (September/October 2013) }\end{array}$ \\
\hline Experiment length $(\mathrm{d})$ & 16 & 13 & 16 \\
Average daily temperature $\left({ }^{\circ} \mathrm{C}\right)$ & $15.4(15.6)$ & $11.1(10.8)$ & $10.5(9.9)$ \\
Average daily maximum temperature $\left({ }^{\circ} \mathrm{C}\right)$ & $20.7(20.5)$ & $14.5(14.6)$ & $14.1(14.0)$ \\
Average daily minimum temperature $\left({ }^{\circ} \mathrm{C}\right)$ & $10.3(10.8)$ & $8.0(7.1)$ & $7.2(5.9)$ \\
Average daily relative humidity $(\%)$ & $70.0(73.1)$ & $87.6(81.7)$ & $85.4(78.9)$ \\
Average daily maximum relative humidity (\%) & $86.8(92.6)$ & $94.9(96.9)$ & $95.2(96.0)$ \\
Average daily minimum relative humidity (\%) & $48.8(53.6)$ & $73.9(66.4)$ & $71.8(61.7)$ \\
Average daily wind speed (m/s) & 1.67 & 1.04 & 1.61 \\
Number of rain days (d) & $6(5.5)$ & $7(7.5)$ & $14(10.4)$ \\
Total rain received (mm) & $14(29)$ & $39(43)$ & $155(61)$ \\
\hline
\end{tabular}

${ }^{1}$ Values in parentheses represent the long-term (40 yr) averages for these periods (long-term data sourced from the SILO climate database: http://www.longpaddock.qld.gov.au/silo/). 
Table 3. The botanical composition (\% species on a DM basis) of the forage offered to the cattle grazing each treatment $(\mathrm{CPM}=$ white clover and plantain mixture; PRG $=$ perennial ryegrass; $\mathrm{RCPM}=$ perennial ryegrass, white clover, and plantain mixture; SAM = spatially adjacent monocultures of perennial ryegrass, white clover, and plantain) in mid (January 2013), late (May 2013), and early (September 2013/October) lactation experiments; values presented are the means \pm SE $(\mathrm{n}=5$ )

\begin{tabular}{|c|c|c|c|c|c|c|c|c|c|c|c|c|}
\hline \multirow[b]{3}{*}{ Item } & \multicolumn{6}{|c|}{ Dryland } & \multicolumn{6}{|c|}{ Irrigated } \\
\hline & \multirow[b]{2}{*}{ CPM } & \multirow[b]{2}{*}{ RCPM } & \multirow[b]{2}{*}{ PRG } & \multicolumn{3}{|c|}{ SAM } & \multirow[b]{2}{*}{ CPM } & \multirow[b]{2}{*}{ RCPM } & \multirow[b]{2}{*}{ PRG } & \multicolumn{3}{|c|}{ SAM } \\
\hline & & & & $\begin{array}{l}\text { Perennial } \\
\text { Ryegrass }\end{array}$ & $\begin{array}{l}\text { White } \\
\text { Clover }\end{array}$ & Plantain & & & & $\begin{array}{l}\text { Perennial } \\
\text { Ryegrass }\end{array}$ & $\begin{array}{l}\text { White } \\
\text { Clover }\end{array}$ & Plantain \\
\hline \multicolumn{13}{|c|}{$\begin{array}{l}\text { Mid lactation experiment } \\
\text { (January 2013) }\end{array}$} \\
\hline Ryegrass & 0 & $82 \pm 9$ & $98 \pm 2$ & $98 \pm 1$ & $4 \pm 0$ & $1 \pm 0$ & 0 & $80 \pm 5$ & $99 \pm 1$ & $98 \pm 1$ & $1 \pm 1$ & $1 \pm 1$ \\
\hline Clover & $7 \pm 5$ & $9 \pm 9$ & 0 & 0 & $52 \pm 15$ & $1 \pm 1$ & $8 \pm 2$ & $4 \pm 2$ & 0 & $1 \pm 1$ & $72 \pm 8$ & $8 \pm 7$ \\
\hline Plantain & $79 \pm 7$ & $5 \pm 3$ & $1 \pm 1$ & 0 & $8 \pm 4$ & $84 \pm 8$ & $86 \pm 2$ & $14 \pm 5$ & 0 & 0 & $4 \pm 1$ & $78 \pm 15$ \\
\hline Weeds & $14 \pm 7$ & $4 \pm 1$ & $1 \pm 1$ & $2 \pm 1$ & $36 \pm 13$ & $14 \pm 8$ & $6 \pm 1$ & $4 \pm 1$ & $1 \pm 0$ & $1 \pm 0$ & $23 \pm 8$ & $13 \pm 7$ \\
\hline \multicolumn{13}{|c|}{$\begin{array}{l}\text { Late lactation experiment } \\
\text { (May 2013) }\end{array}$} \\
\hline Ryegrass & $16 \pm 13$ & $67 \pm 7$ & $95 \pm 4$ & $95 \pm 4$ & $4 \pm 0$ & 0 & 0 & $59 \pm 4$ & $100 \pm 0$ & $100 \pm 0$ & $2 \pm 0$ & $1 \pm 0$ \\
\hline Clover & $29 \pm 17$ & 0 & 0 & 0 & $65 \pm 10$ & 0 & $10 \pm 3$ & $4 \pm 2$ & 0 & 0 & $86 \pm 5$ & 0 \\
\hline Plantain & $55 \pm 22$ & $32 \pm 7$ & $4 \pm 0$ & 0 & $1 \pm 0$ & $99 \pm 1$ & $82 \pm 6$ & $36 \pm 5$ & 0 & 0 & 0 & $97 \pm 1$ \\
\hline Weeds & 0 & $1 \pm 0$ & $1 \pm 0$ & $5 \pm 4$ & $30 \pm 10$ & $1 \pm 1$ & $8 \pm 5$ & $1 \pm 1$ & 0 & 0 & $12 \pm 4$ & $2 \pm 1$ \\
\hline \multicolumn{13}{|c|}{$\begin{array}{l}\text { Early lactation experiment } \\
\text { (September/October 2013) }\end{array}$} \\
\hline Ryegrass & 0 & $75 \pm 6$ & $99 \pm 1$ & $96 \pm 4$ & 0 & $1 \pm 1$ & 0 & $53 \pm 10$ & $96 \pm 2$ & $97 \pm 2$ & $1 \pm 1$ & $4 \pm 3$ \\
\hline Clover & $12 \pm 5$ & $1 \pm 1$ & 0 & 0 & $67 \pm 7$ & 0 & $7 \pm 1$ & $2 \pm 1$ & $1 \pm 1$ & $1 \pm 1$ & $64 \pm 4$ & 0 \\
\hline Plantain & $79 \pm 5$ & $24 \pm 6$ & $1 \pm 1$ & 0 & $1 \pm 1$ & $96 \pm 3$ & $77 \pm 6$ & $43 \pm 9$ & 0 & 0 & $2 \pm 1$ & $86 \pm 4$ \\
\hline Weeds & $9 \pm 4$ & 0 & 0 & $4 \pm 4$ & $32 \pm 8$ & $3 \pm 3$ & $16 \pm 6$ & $2 \pm 2$ & $3 \pm 2$ & $2 \pm 2$ & $33 \pm 4$ & $10 \pm 4$ \\
\hline
\end{tabular}


Table 4. The nutritive value parameters of the forage offered to the cattle grazing each treatment $(\mathrm{CPM}=$ white clover and plantain mixture; PRG $=$ perennial ryegrass; $\mathrm{RCPM}$ = perennial ryegrass, white clover, and plantain mixture; SAM = spatially adjacent monocultures of perennial ryegrass, white clover, and plantain) and the concentrate dairy pellet in the mid (January 2013), late (May 2013), and early (September/October 2013) lactation experiments; values presented are the means \pm SE $(\mathrm{n}=5$ )

\begin{tabular}{|c|c|c|c|c|c|c|c|c|c|c|c|c|c|}
\hline \multirow[b]{3}{*}{ Item } & \multicolumn{6}{|c|}{ Dryland } & \multicolumn{6}{|c|}{ Irrigated } & \multirow[b]{3}{*}{$\begin{array}{l}\text { Dairy } \\
\text { Pellet }\end{array}$} \\
\hline & \multirow[b]{2}{*}{$\mathrm{CPM}$} & \multirow[b]{2}{*}{$\mathrm{RCPM}$} & \multirow[b]{2}{*}{ PRG } & \multicolumn{3}{|c|}{ SAM } & \multirow[b]{2}{*}{ CPM } & \multirow[b]{2}{*}{$\mathrm{RCPM}$} & \multirow[b]{2}{*}{ PRG } & \multicolumn{3}{|c|}{ SAM } & \\
\hline & & & & $\begin{array}{l}\text { Perennial } \\
\text { Ryegrass }\end{array}$ & $\begin{array}{l}\text { White } \\
\text { Clover }\end{array}$ & Plantain & & & & $\begin{array}{l}\text { Perennial } \\
\text { Ryegrass }\end{array}$ & $\begin{array}{l}\text { White } \\
\text { Clover }\end{array}$ & Plantain & \\
\hline \multicolumn{14}{|l|}{$\begin{array}{l}\text { Mid lactation } \\
\text { experiment } \\
\text { (January 2013) }\end{array}$} \\
\hline $\mathrm{CP}(\%)$ & $13.1 \pm 0.8$ & $12.7 \pm 0.8$ & $13.5 \pm 0.8$ & $12.9 \pm 0.4$ & $18.6 \pm 1.5$ & $12.2 \pm 0.4$ & $17.8 \pm 1.3$ & $15.4 \pm 1.5$ & $16.5 \pm 1.2$ & $15.8 \pm 1.4$ & $22.6 \pm 1.0$ & $16.9 \pm 1.1$ & 15.3 \\
\hline $\operatorname{ADF}(\%)$ & $37.4 \pm 0.9$ & $33.0 \pm 0.9$ & $31.8 \pm 0.9$ & $34.7 \pm 0.9$ & $31.0 \pm 2.9$ & $38.1 \pm 1.1$ & $33.3 \pm 2.3$ & $30.4 \pm 1.3$ & $31.4 \pm 1.2$ & $31.9 \pm 1.0$ & $27.5 \pm 1.1$ & $33.6 \pm 0.9$ & 7.7 \\
\hline NDF $(\%)$ & $47.9 \pm 1.1$ & $55.0 \pm 1.9$ & $54.8 \pm 1.6$ & $56.7 \pm 0.8$ & $39.9 \pm 4.1$ & $47.9 \pm 0.6$ & $44.0 \pm 1.1$ & $48.9 \pm 1.0$ & $52.5 \pm 1.5$ & $52.1 \pm 0.9$ & $36.8 \pm 1.9$ & $42.6 \pm 1.7$ & 31.1 \\
\hline $\begin{array}{l}\text { In vitro DM } \\
\text { digestibility (\%) }\end{array}$ & $54.9 \pm 1.6$ & $63.7 \pm 1.3$ & $64.5 \pm 1.3$ & $63.9 \pm 1.0$ & $66.7 \pm 2.8$ & $63.9 \pm 1.0$ & $64.3 \pm 1.2$ & $72.3 \pm 1.0$ & $70.5 \pm 1.7$ & $71.9 \pm 1.1$ & $71.3 \pm 2.4$ & $63.5 \pm 2.0$ & 70.1 \\
\hline $\begin{array}{l}\text { Estimated ME } \\
(\mathrm{MJ} / \mathrm{kg} \text { of } \mathrm{DM})\end{array}$ & $7.8 \pm 0.3$ & $9.2 \pm 0.1$ & $9.4 \pm 0.2$ & $9.3 \pm 0.1$ & $9.7 \pm 0.5$ & $7.5 \pm 0.1$ & $9.3 \pm 0.2$ & $10.6 \pm 0.2$ & $10.3 \pm 0.3$ & $10.6 \pm 0.3$ & $10.5 \pm 0.2$ & $9.2 \pm 0.4$ & 11.4 \\
\hline \multicolumn{14}{|l|}{$\begin{array}{l}\text { Late lactation } \\
\text { experiment } \\
\text { (May 2013) }\end{array}$} \\
\hline CP (\%) & $27.9 \pm 1.0$ & $28.3 \pm 1.1$ & $27.5 \pm 1.0$ & $26.3 \pm 1.3$ & $31.0 \pm 0.6$ & $26.3 \pm 1.2$ & $27.1 \pm 1.2$ & $26.4 \pm 1.6$ & $25.4 \pm 1.2$ & $24.7 \pm 2.0$ & $31.1 \pm 0.1$ & $23.8 \pm 1.0$ & 14.5 \\
\hline $\operatorname{ADF}(\%)$ & $31.5 \pm 0.8$ & $26.4 \pm 1.0$ & $25.7 \pm 0.7$ & $24.4 \pm 0.5$ & $25.6 \pm 2.1$ & $32.3 \pm 0.9$ & $29.7 \pm 0.8$ & $28.1 \pm 0.5$ & $25.6 \pm 1.1$ & $26.2 \pm 0.9$ & $24.9 \pm 2.1$ & $32.7 \pm 0.4$ & 9.0 \\
\hline NDF $(\%)$ & $41.1 \pm 1.2$ & $45.4 \pm 0.9$ & $46.1 \pm 0.9$ & $47.2 \pm 0.9$ & $35.7 \pm 2.4$ & $39.0 \pm 0.6$ & $37.2 \pm 1.7$ & $43.2 \pm 0.6$ & $44.8 \pm 0.5$ & $46.4 \pm 0.8$ & $31.0 \pm 1.7$ & $39.5 \pm 1.4$ & 27.8 \\
\hline $\begin{array}{l}\text { In vitro DM } \\
\text { digestibility (\%) }\end{array}$ & $69.3 \pm 1.0$ & $75.1 \pm 0.8$ & $76.1 \pm 0.8$ & $76.3 \pm 0.9$ & $74.3 \pm 1.0$ & $67.9 \pm 1.2$ & $72.5 \pm 1.1$ & $76.5 \pm 0.8$ & $79.4 \pm 0.7$ & $79.9 \pm 0.7$ & $81.3 \pm 0.4$ & $70.7 \pm 0.8$ & 72.3 \\
\hline $\begin{array}{c}\text { Estimated ME } \\
(\mathrm{MJ} / \mathrm{kg} \text { of } \mathrm{DM})\end{array}$ & $10.1 \pm 0.2$ & $11.1 \pm 0.1$ & $11.2 \pm 0.1$ & $11.3 \pm 0.1$ & $11.0 \pm 0.2$ & $9.9 \pm 0.2$ & $10.7 \pm 0.2$ & $11.3 \pm 0.1$ & $11.8 \pm 0.1$ & $11.9 \pm 0.1$ & $12.1 \pm 0.1$ & $10.4 \pm 0.1$ & 11.9 \\
\hline \multicolumn{14}{|l|}{$\begin{array}{l}\text { Early lactation } \\
\text { experiment } \\
\text { (September/ } \\
\text { October 2013) }\end{array}$} \\
\hline CP (\%) & $25.7 \pm 1.8$ & $25.1 \pm 1.5$ & $24.9 \pm 1.5$ & $25.5 \pm 2.2$ & $31.7 \pm 0.9$ & $25.6 \pm 1.2$ & $19.9 \pm 1.6$ & $18.6 \pm 1.9$ & $18.7 \pm 2.1$ & $17.1 \pm 1.9$ & $26.6 \pm 1.1$ & $15.4 \pm 0.6$ & 11.1 \\
\hline $\operatorname{ADF}(\%)$ & $29.2 \pm 0.8$ & $28.1 \pm 0.9$ & $27.4 \pm 0.6$ & $27.1 \pm 0.6$ & $23.3 \pm 1.1$ & $29.3 \pm 0.7$ & $28.6 \pm 0.9$ & $28.8 \pm 0.9$ & $27.9 \pm 0.3$ & $27.6 \pm 0.7$ & $23.5 \pm 1.3$ & $29.6 \pm 0.6$ & 5.2 \\
\hline NDF $(\%)$ & $37.0 \pm 0.3$ & $48.5 \pm 1.4$ & $52.3 \pm 1.4$ & $51.5 \pm 1.2$ & $33.1 \pm 1.9$ & $38.4 \pm 0.7$ & $37.6 \pm 1.7$ & $44.5 \pm 2.8$ & $50.0 \pm 0.7$ & $52.1 \pm 1.5$ & $36.8 \pm 2.2$ & $37.0 \pm 0.9$ & 14.5 \\
\hline $\begin{array}{l}\text { In vitro DM } \\
\text { digestibility (\%) }\end{array}$ & $69.7 \pm 1.1$ & $70.5 \pm 1.3$ & $68.5 \pm 0.5$ & $70.3 \pm 0.6$ & $75.1 \pm 1.5$ & $70.3 \pm 0.7$ & $71.1 \pm 0.5$ & $72.5 \pm 2.1$ & $73.5 \pm 1.5$ & $72.1 \pm 1.9$ & $75.7 \pm 1.1$ & $71.1 \pm 0.0$ & 77.2 \\
\hline $\begin{array}{c}\text { Estimated ME } \\
(\mathrm{MJ} / \mathrm{kg} \text { of } \mathrm{DM})\end{array}$ & $10.2 \pm 0.2$ & $10.3 \pm 0.2$ & $10.0 \pm 0.1$ & $10.3 \pm 0.1$ & $11.1 \pm 0.2$ & $10.6 \pm 0.1$ & $10.4 \pm 0.1$ & $10.7 \pm 0.3$ & $10.8 \pm 0.2$ & $10.6 \pm 0.3$ & $11.2 \pm 0.2$ & $10.4 \pm 0.0$ & 12.2 \\
\hline
\end{tabular}


the milk volume produced from cows grazing the SAM or RCPM was greater than for cows grazing either the PRG or CPM treatments.

At the commencement of the mid lactation experiment, milk fat concentration was initially greater for cows allocated to the PRG treatment (Table 5). After grazing the forage treatments, the milk fat concentration of cows grazing the RCPM and SAM was greater than for cows grazing the CPM treatment, but less than for cows grazing the PRG treatment. This segregation did not occur for daily milk fat yield, with cows grazing the RCPM and SAM treatments producing the same yield of milk fat as cows grazing the PRG treatment and a greater yield than cows grazing the CPM treatment. The milk protein concentration and total daily milk protein yield from cows grazing both the RCPM and PRG treatments was greater than for cows grazing the CPM and SAM treatments. Milk protein yield of cows grazing the SAM was also greater than for cows grazing the CPM treatment. Whereas the milk lactose concentration was greatest from cows grazing the RCPM forage treatment, this did not translate to differences in milk lactose yield among the forage treatments.

We observed no difference in milk fat concentration between the forage treatments in the late lactation experiment. Differences in milk volume led to milk fat yield of cows grazing the RCPM, PRG, and SAM forage treatments being greater than for cows grazing the CPM treatment. Milk protein concentration from cows grazing the RCPM treatment was greater than for cows grazing either the CPM or SAM treatments, whereas the protein concentration from cows grazing the PRG treatment was greater than the SAM treat- ment cow's protein concentration. These differences, coupled with the difference in milk volume, resulted in milk protein yield being greatest in cows grazing the RCPM treatment. Furthermore, the cows grazing the PRG and SAM treatments had a greater milk protein yield than cows grazing the CPM treatment. Milk lactose concentration was greater for cows grazing the CPM treatment than for either the cows grazing the PRG or SAM treatments. However, due to differences in milk volume, total lactose yield was lowest from cows grazing the CPM forage treatment.

No influence of forage treatment was noted on the milk concentrations of fat, protein, or lactose during the early lactation experiment. However, the differences in milk volumes led to differences in milk protein yield among the treatments, with cows grazing the SAM forage treatment producing a greater amount of protein compared with cows grazing the PRG and CPM treatments.

\section{Blood Metabolite Levels}

Blood BHB and fatty acid concentrations during the response period of each experiment were well below levels indicative of a negative energy balance (Figure 3 ). For the early lactation experiment, blood sample BHB and fatty acid concentrations suggest cows were in energy deficit before commencement of the experiment. However, by the time the response period had commenced, the concentrations of BHB and fatty acids in the blood had decreased, indicating no energy deficit during the response period. The forage treatments had a small effect on blood BHB concentration during the mid lactation experiment, with the greatest levels
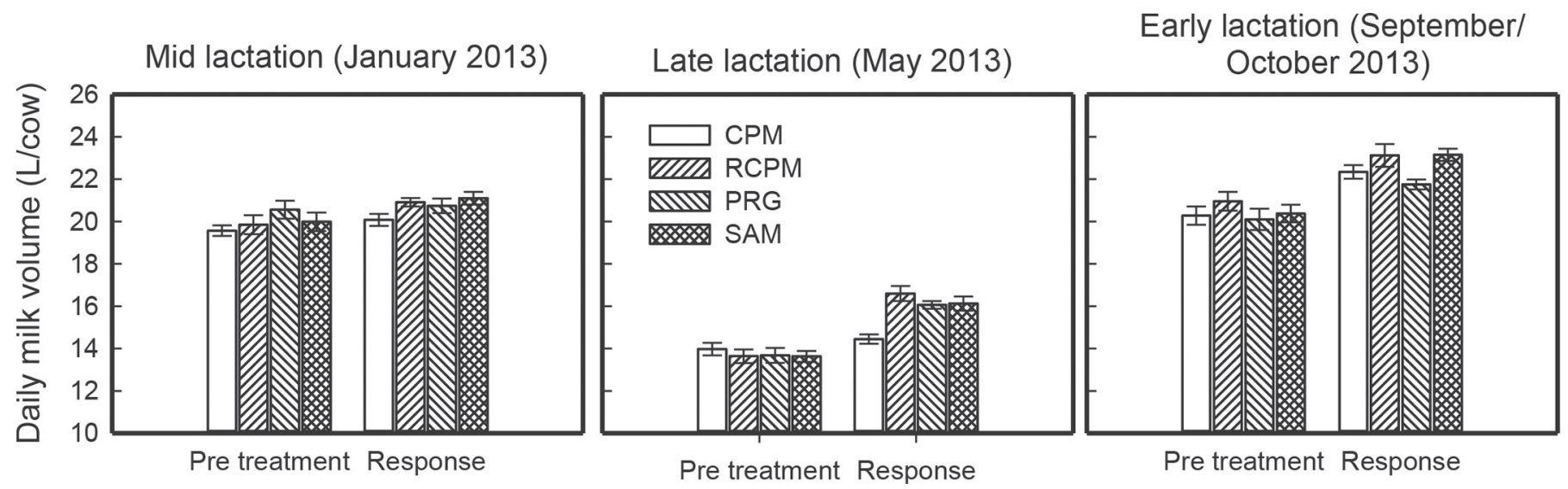

Figure 2. The average daily milk volume per cow from cows grazing a white clover and plantain mixture (CPM), a perennial ryegrass, white clover, and plantain mixture (RCPM), a perennial ryegrass monoculture (PRG), and spatially adjacent monocultures (SAM) of perennial ryegrass, white clover, and plantain during the pretreatment (immediately before the experiment commencing) and response (last $5 \mathrm{~d}$ of each experiment) phases of the mid lactation (January 2013), late lactation (May 2013), and early lactation (September/October 2013) experiments. Error bars represent SEM $(\mathrm{n}=4)$. 
Table 5. The concentration and yield of milk fat, milk protein, and milk lactose during the pretreatment (Pre.) and response (Resp.) periods of the mid, late, and early lactation experiments where cows were grazed on either a white clover, plantain mixture (CPM), a perennial ryegrass, white clover, plantain mixture (RCPM), a monoculture of perennial ryegrass (PRG), or spatially adjacent monocultures of perennial ryegrass, white clover, and plantain (SAM)

\begin{tabular}{|c|c|c|c|c|c|c|c|c|c|c|c|c|}
\hline \multirow[b]{2}{*}{ Item } & \multicolumn{6}{|c|}{ Concentration (\%) } & \multicolumn{6}{|c|}{ Daily yield (g/cow) } \\
\hline & $\mathrm{CPM}$ & $\mathrm{RCPM}$ & PRG & SAM & $P$-value & $\mathrm{SED}^{1}$ & $\mathrm{CPM}$ & $\mathrm{RCPM}$ & PRG & SAM & $P$-value & $\mathrm{SED}^{1}$ \\
\hline \multirow{2}{*}{\multicolumn{13}{|c|}{$\begin{array}{l}\text { Mid lactation experiment } \\
\text { (January 2013) }\end{array}$}} \\
\hline & & & & & & & & & & & & \\
\hline Pre. & $3.95^{\mathrm{a}}$ & $4.20^{\mathrm{a}}$ & $4.68^{\mathrm{b}}$ & $3.95^{\mathrm{a}}$ & $<0.01$ & 0.140 & $696^{\mathrm{a}}$ & $713^{\mathrm{a}}$ & $882^{\mathrm{b}}$ & $739^{\mathrm{ab}}$ & $<0.01$ & 44.9 \\
\hline Resp. & $3.70^{\mathrm{a}}$ & $4.21^{\mathrm{b}}$ & $4.41^{\mathrm{c}}$ & $4.18^{\mathrm{b}}$ & $<0.001$ & 0.089 & $745^{\mathrm{a}}$ & $880^{\mathrm{b}}$ & $919^{\mathrm{b}}$ & $869^{\mathrm{b}}$ & $<0.001$ & 24.7 \\
\hline \multicolumn{13}{|l|}{ Protein } \\
\hline Pre. & 2.88 & 3.01 & 3.05 & 2.91 & NS & 0.078 & 508 & 506 & 574 & 543 & NS & 24.6 \\
\hline Resp. & $3.04^{\mathrm{a}}$ & $3.17^{\mathrm{b}}$ & $3.16^{\mathrm{b}}$ & $3.04^{\mathrm{a}}$ & $<0.001$ & 0.032 & $607^{\mathrm{a}}$ & $663^{\mathrm{c}}$ & $661^{\mathrm{c}}$ & $632^{\mathrm{b}}$ & $<0.001$ & 11.8 \\
\hline \multicolumn{13}{|l|}{ Lactose } \\
\hline Pre. & 4.94 & 4.90 & 5.00 & 4.94 & NS & 0.048 & 871 & 836 & 943 & 926 & NS & 46.3 \\
\hline Resp. & $4.95^{\mathrm{ab}}$ & $4.96^{\mathrm{b}}$ & $4.90^{\mathrm{a}}$ & $4.92^{\mathrm{a}}$ & $<0.05$ & 0.021 & 993 & 1,039 & 1,027 & 1,027 & NS & 20.7 \\
\hline \multirow{2}{*}{\multicolumn{13}{|c|}{$\begin{array}{l}\text { Late lactation experiment } \\
\text { (May 2013) } \\
\text { Fat }\end{array}$}} \\
\hline & & & & & & & & & & & & \\
\hline Pre. & 4.59 & 4.67 & 4.65 & 4.45 & NS & 0.252 & 609 & 608 & 575 & 587 & NS & 40.9 \\
\hline Resp. & 4.22 & 4.23 & 4.44 & 4.22 & NS & 0.112 & $608^{\mathrm{a}}$ & $714^{\mathrm{b}}$ & $707^{\mathrm{b}}$ & $690^{\mathrm{b}}$ & $<0.001$ & 18.3 \\
\hline \multicolumn{13}{|l|}{ Protein } \\
\hline Pre. & 3.49 & 3.56 & 3.63 & 3.51 & NS & 0.093 & 465 & 462 & 450 & 462 & NS & 21.7 \\
\hline Resp. & $3.59^{\mathrm{ab}}$ & $3.69^{\mathrm{c}}$ & $3.66^{\mathrm{bc}}$ & $3.52^{\mathrm{a}}$ & $<0.001$ & 0.033 & $519^{\mathrm{a}}$ & $624^{\mathrm{c}}$ & $588^{\mathrm{b}}$ & $575^{\mathrm{b}}$ & $<0.001$ & 11.2 \\
\hline \multicolumn{13}{|l|}{ Lactose } \\
\hline Pre. & 5.10 & 5.06 & 4.94 & 5.05 & NS & 0.069 & 678 & 664 & 628 & 669 & NS & 31.7 \\
\hline Resp. & $4.88^{\mathrm{b}}$ & $4.85^{\mathrm{ab}}$ & $4.82^{\mathrm{a}}$ & $4.81^{\mathrm{a}}$ & $<0.05$ & 0.026 & $706^{\mathrm{a}}$ & $826^{\mathrm{c}}$ & $783^{\mathrm{b}}$ & $790^{\mathrm{bc}}$ & $<0.001$ & 17.1 \\
\hline \multirow{2}{*}{\multicolumn{13}{|c|}{$\begin{array}{l}\text { Early lactation experiment } \\
\text { (September/October 2013) } \\
\text { Fat }\end{array}$}} \\
\hline & & & & & & & & & & & & \\
\hline Pre. & 3.98 & 4.05 & 3.67 & 4.15 & NS & 0.238 & 796 & 902 & 750 & 850 & NS & 73.8 \\
\hline Resp. & 4.26 & 4.11 & 4.21 & 4.20 & NS & 0.136 & 940 & 926 & 906 & 962 & NS & 39.8 \\
\hline \multicolumn{13}{|l|}{ Protein } \\
\hline Pre. & 3.05 & 3.02 & 2.94 & 3.00 & NS & 0.076 & 630 & 668 & 601 & 611 & NS & 52.5 \\
\hline Resp. & 3.12 & 3.11 & 3.06 & 3.11 & NS & 0.043 & $687^{\mathrm{a}}$ & $706^{\mathrm{ab}}$ & $663^{\mathrm{a}}$ & $715^{\mathrm{b}}$ & $<0.05$ & 21.2 \\
\hline \multicolumn{13}{|l|}{ Lactose } \\
\hline Pre. & 4.74 & 5.11 & 5.01 & 4.91 & NS & 0.136 & 996 & 1,130 & 1,029 & 1,005 & NS & 98.6 \\
\hline Resp. & 5.03 & 5.01 & 5.01 & 5.04 & NS & 0.025 & 1,109 & 1,139 & 1,088 & 1,157 & NS & 31.7 \\
\hline
\end{tabular}

${ }^{\mathrm{a}-\mathrm{c}}$ Means within a row with different superscripts differ $(P<0.05)$.

$\underset{ }{\complement} \mathrm{SED}=$ standard error of the difference. 
Mid Lactation (January 2013) Late Lactation (May 2013)
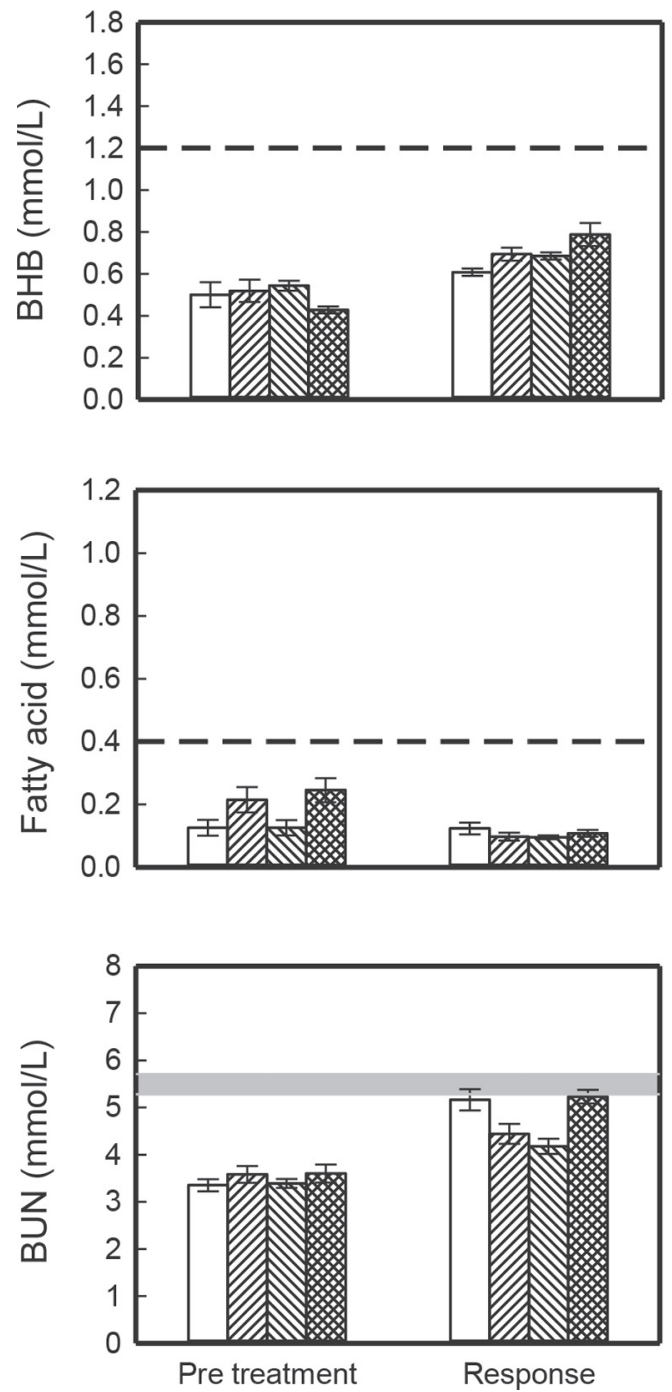
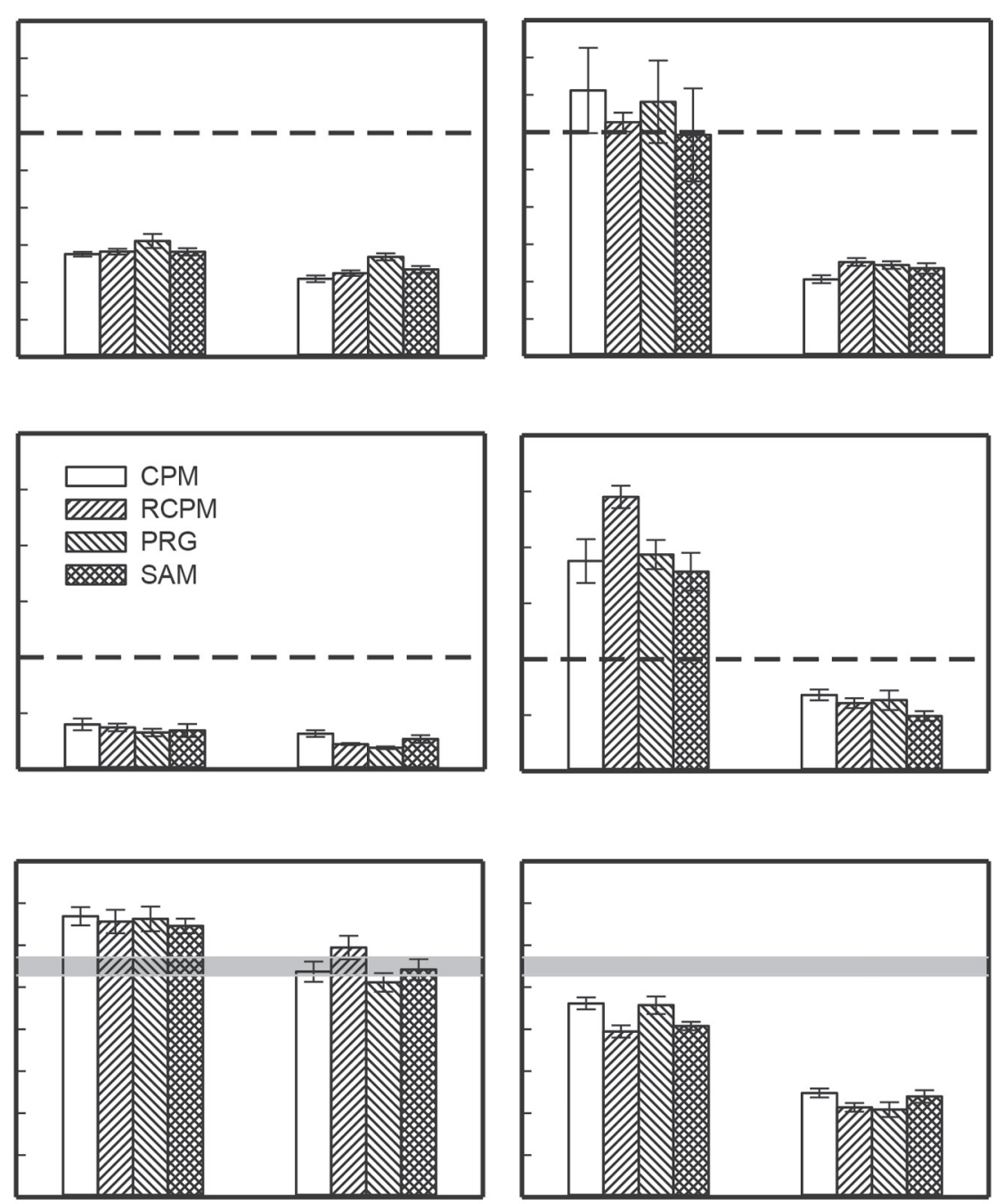

Pre treatment

\section{Early Lactation (September/ October 2013)}

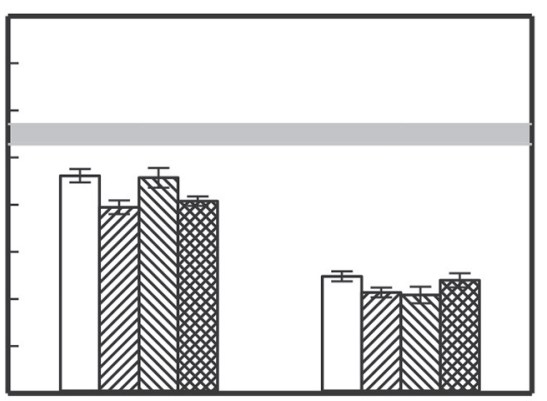

Pre treatment

Response

Figure 3. Beta-hydroxybutyrate, fatty acid, and BUN concentration in the blood from cows grazing a white clover and plantain mixture $(\mathrm{CPM})$, a perennial ryegrass, white clover, and plantain mixture (RCPM), a perennial ryegrass monoculture (PRG), and spatially adjacent monocultures (SAM) of perennial ryegrass, white clover, and plantain during the pretreatment (immediately before the experiment) and response phases (the last $5 \mathrm{~d}$ of each experiment) of the mid lactation (January 2013), late lactation (May 2013), and early lactation (September/ October 2013) experiments. Error bars represent SEM. The broken horizontal lines represent the thresholds suggested by Duffield et al. (2009) and Ospina et al. (2010) for BHB and fatty acid concentrations above which suggests an energy deficit. The horizontal gray bar is the range in BUN considered by Roseler et al. (1993) and Baker et al. (1995) as indicative of a diet with an adequate CP content.

of blood BHB present in the SAM treatment and the lowest levels found in the CPM treatment. In the late lactation experiment, the forage treatments had a small influence on blood fatty acid concentration, with the CPM treatment having a greater concentration than found in the blood of cows from the other treatments. In the early lactation experiment, cows grazing the CPM treatment had a greater blood fatty acid concentration than those grazing the SAM treatment and a lower blood BHB concentration than bloods from cows grazing the other forage treatments.

In the mid lactation experiment, BUN concentration of cows grazing the RCPM and PRG forage treatments were lower than cows grazing the CPM and SAM treatments. In this experiment, the BUN concentration of cows grazing the RCPM and PRG treatments were below the range indicating adequate $\mathrm{CP}$ levels in cow diets. In the late lactation experiment, BUN concentra- 
Table 6. Live weight at the beginning, after acclimation, and at the end of each experiment and average daily change in live weight during the measurement period and the full experiment for each of the mid, late, and early lactation experiments where cows grazed on either a white clover, plantain mixture (CPM), a perennial ryegrass, white clover, plantain mixture (RCPM), a monoculture of perennial ryegrass (PRG), or spatially adjacent monocultures of perennial ryegrass, white clover, and plantain (SAM)

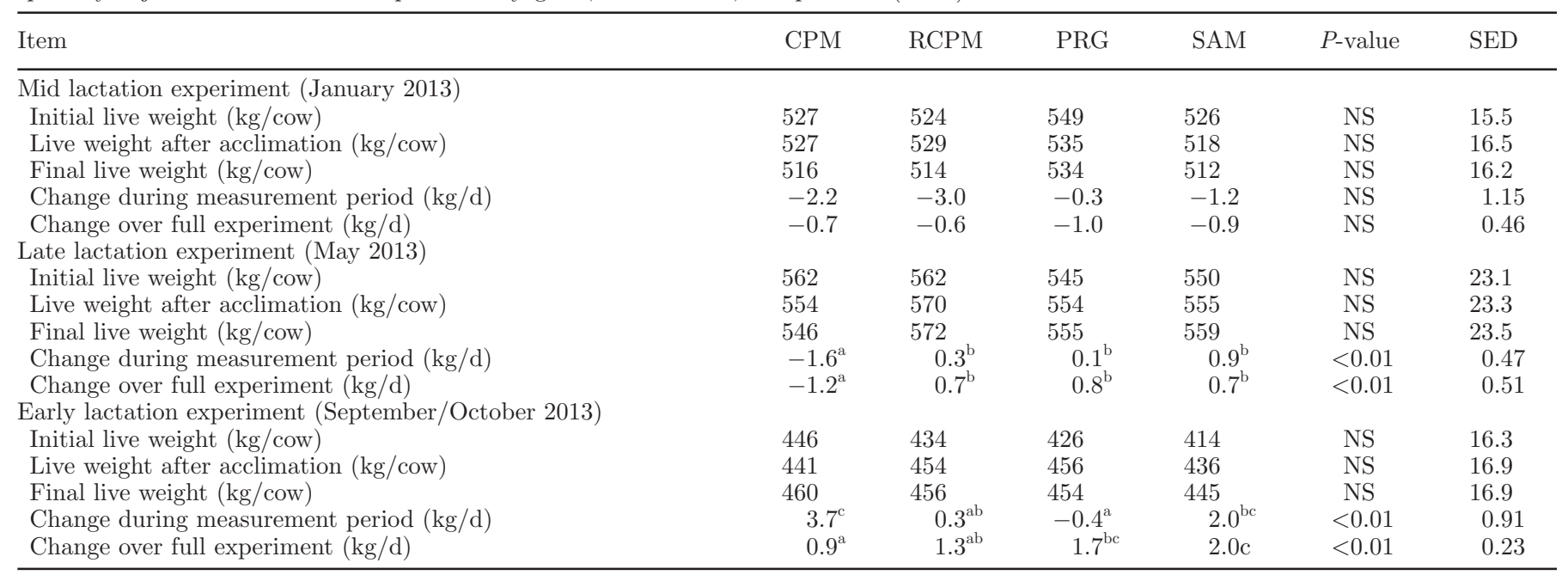

${ }^{\mathrm{a}-\mathrm{c}}$ Means within a row with different superscripts differ $(P<0.05)$.

tion of all cows indicated that $\mathrm{CP}$ content of all diets were adequate, whereas in the early lactation experiment the BUN concentration of cows from all treatments indicate a dietary CP deficiency.

\section{Live Weight Change}

We found no significant effect of the forage treatments on live weight change during the mid lactation experiment (Table 6), with all cows losing weight at an average of $1.7 \mathrm{~kg} / \mathrm{d}$ during the response period. In the late lactation experiment cows grazing the CPM treatment lost weight, whereas cows grazing all other forage treatments gained weight. In the early lactation experiment, cows grazing the SAM had greater live weight gains than cows in the CPM and RCPM treatments over the full experimental period. During the response period of the early lactation experiment, cows grazing the CPM and SAM had greater live weight gain than cows grazing the PRG treatment.

\section{Forage Intake and Selection Differentials}

The CPM treatment had the lowest pregrazing biomass during the late and early lactation experiments. For the mid lactation experiment the CPM and RCPM treatments had a lower pregrazing biomass than the PRG treatment (Table 7). In the SAM, across all 3 experiments white clover consistently had the lowest pregrazing biomass and perennial ryegrass consistently had the highest pregrazing biomass.
In the mid lactation experiment, forage intake, estimated from plate meter readings, was greatest for cows grazing the PRG treatment compared with cows grazing the SAM treatment. For the early and late lactation experiments, cows grazing the RCPM had greater forage intake when compared with all other treatments. However, in the early lactation experiment, cows grazing the PRG treatment also had greater daily forage intake than cows grazing either the CPM or SAM treatments.

The calculated selection differentials indicated cows grazing the RCPM treatment selected against perennial ryegrass during the mid lactation experiment but not in the other experimental periods (Table 8; indicated by a selection differential less than 1); these cows showed a selective preference for white clover, as indicated by a selection differential greater than 1 . This preference for white clover was greatest for cows grazing the CPM and RCPM. The cows grazing the RCPM and SAM selected for plantain in the mid and early lactation experiments. In the mid lactation experiment, the selection for plantain was greater in the RCPM compared with SAM, which was in turn was greater than that seen in the CPM treatment. In the early lactation experiment the cows grazing the SAM had a greater selection differential for plantain than cows grazing the CPM treatment.

In the late lactation experiment, the selection for $\mathrm{CP}$ was greater for cows grazing the PRG treatment than for cows grazing the CPM treatment. In the early lactation experiment, the selection for $\mathrm{CP}$ was greater in the SAM treatment than the CPM, RCPM, and 
Table 7. Daily pre- and postgrazing biomass, average estimated daily pasture intake (as estimated using a calibrated rising plate meter), and calculated forage intake (calculated from energy requirements) of cows grazing perennial ryegrass monocultures (PRG), perennial ryegrass, white clover, and plantain mixtures (RCPM), white clover plantain mixtures $(\mathrm{CPM})$, or spatially adjacent monocultures (SAM) of perennial ryegrass, white clover, and plantain in each of the 3 experiments

\begin{tabular}{|c|c|c|c|c|c|c|c|c|}
\hline \multirow[b]{2}{*}{ Item } & \multirow[b]{2}{*}{$\mathrm{CPM}$} & \multirow[b]{2}{*}{ RCPM } & \multirow[b]{2}{*}{ PRG } & \multicolumn{3}{|c|}{ SAM } & \multirow[b]{2}{*}{$P$-value } & \multirow[b]{2}{*}{ SED } \\
\hline & & & & $\begin{array}{l}\text { Perennial } \\
\text { Ryegrass }\end{array}$ & $\begin{array}{l}\text { White } \\
\text { Clover }\end{array}$ & Plantain & & \\
\hline \multicolumn{9}{|l|}{ Mid lactation experiment (January 2013) } \\
\hline Pregrazing biomass ( $\mathrm{kg}$ of $\mathrm{DM} / \mathrm{ha}$ ) & $3,133^{\mathrm{c}}$ & $3,110^{\mathrm{c}}$ & $4,030^{\mathrm{d}}$ & $4,173^{\mathrm{e}}$ & $2,094^{\mathrm{a}}$ & $2,738^{\mathrm{b}}$ & $<0.001$ & 29.1 \\
\hline Postgrazing biomass (kg of DM/ha) & $2,201^{\mathrm{d}}$ & $2,045^{\mathrm{c}}$ & $2,705^{\mathrm{f}}$ & $2,621^{\mathrm{e}}$ & $1,299^{\mathrm{a}}$ & $1,550^{\mathrm{b}}$ & $<0.001$ & 25.3 \\
\hline Estimated pasture intake (kg of DM/cow per day) & $11.4^{\mathrm{ab}}$ & $11.3^{\mathrm{ab}}$ & $12.0^{\mathrm{b}}$ & & $10.9^{\mathrm{a}}$ & & $<0.001$ & 0.31 \\
\hline Calculated pasture intake (kg of DM/cow per day) & 13.9 & 12.9 & 12.8 & & 12.8 & & & \\
\hline \multicolumn{9}{|l|}{ Late lactation experiment (May 2013) } \\
\hline Pregrazing biomass (kg of DM/ha) & $1,429^{\mathrm{b}}$ & $2,230^{\mathrm{d}}$ & $2,330^{\mathrm{e}}$ & $2,274^{\mathrm{d}}$ & $971^{\mathrm{a}}$ & $1,775^{\mathrm{c}}$ & $<0.001$ & 24.2 \\
\hline Postgrazing biomass (kg of DM/ha) & $752^{\mathrm{b}}$ & $1,582^{\mathrm{d}}$ & $1,698^{\mathrm{e}}$ & $1,609^{\mathrm{d}}$ & $629^{\mathrm{a}}$ & $1,047^{\mathrm{c}}$ & $<0.001$ & 16.2 \\
\hline Estimated pasture (kg of DM/cow per day) & $10.8^{\mathrm{a}}$ & $12.8^{\mathrm{b}}$ & $11.3^{\mathrm{a}}$ & & $10.2^{\mathrm{a}}$ & & $<0.001$ & 0.38 \\
\hline Calculated pasture intake (kg of DM/cow per day) & 8.7 & 12.7 & 11.7 & & 14.1 & & & \\
\hline \multicolumn{9}{|l|}{ Early lactation experiment (September/October 2013) } \\
\hline Pregrazing biomass (kg of DM/ha) & $2,629^{\mathrm{c}}$ & $3,399^{\mathrm{f}}$ & $3,270^{\mathrm{e}}$ & $3,010^{\mathrm{d}}$ & $1,349^{\mathrm{a}}$ & $2,169^{\mathrm{b}}$ & $<0.001$ & 26.5 \\
\hline Postgrazing biomass (kg of DM/ha) & $1,766^{\mathrm{c}}$ & $2,230^{\mathrm{e}}$ & $2,224^{\mathrm{e}}$ & $2,161^{\mathrm{d}}$ & $923^{\mathrm{a}}$ & $1,363^{\mathrm{b}}$ & $<0.001$ & 18.9 \\
\hline Estimated pasture intake ( $\mathrm{kg}$ of DM/cow per day) & $11.1^{\mathrm{a}}$ & $13.7^{\mathrm{c}}$ & $12.8^{\mathrm{b}}$ & & $10.9^{\mathrm{a}}$ & & $<0.001$ & 0.31 \\
\hline Calculated pasture intake (kg of DM/cow per day) & 14.9 & 13.7 & 14.5 & & 14.8 & & & \\
\hline
\end{tabular}

${ }^{\mathrm{a} f}$ Means within a row with different superscripts differ $(P<0.05)$.

${ }^{1}$ Significant treatment effects were determined using a repeated measures REML (and are indicated as not significant), and the significant differences between treatment means was determined using LSD (and is indicated by means with different scripts).

${ }^{*} P<0.05,{ }^{* *} P<0.01$, and ${ }^{* * *} P<0.001$. 
PRG treatments. In the same experiment, the cows grazing the SAM had the greatest selection against ADF. In the mid lactation experiment the cows grazing the RCPM and the SAM had a greater selection against NDF compared with cows grazing the CPM. Supplementary Table S3 (http://dx.doi.org/10.3168/ jds.2015-10542) presents the botanical composition and nutritive value of each of the treatments for pre- and postgrazing periods.

\section{DISCUSSION}

Milk production (volume and components) increased in both the RCPM and SAM treatments compared with the PRG treatment during the early lactation experiment, whereas in the mid lactation experiment the increase in milk components was greatest in the RCPM and SAM treatments. The forage treatments included a forb component that represented pastures with greater diversity than either the perennial ryegrass monocultures or perennial ryegrass-white clover pastures traditionally used for pasture-based dairy production in Australia and New Zealand. Increases in milk volume and milk protein production above that achieved from perennial ryegrass-white clover mixtures have been observed from cows grazing a 6 -species mix that included plantain and white clover on the Canterbury Plains of New Zealand (Totty et al., 2013). A similar result was also found by Woodward et al.
(2013), who noted an increase in milk production in autumn from cows grazing a diverse pasture mixture of 6 species (including forbs and legumes) in the Waikato region of New Zealand. In the western Victoria dairy region of Australia, no difference in milk production (volume or components) was observed between cows grazing perennial ryegrass monocultures, perennial ryegrass, and chicory mixtures or chicory monocultures (Muir et al., 2014). In Pennsylvania, Soder et al. (2006) found increasing pasture diversity by including additional grass, forb, and legume species beyond an orchard grass (Dactylis glomerata)-white clover mixture had no effect on milk production. Research comparing milk production from monocultures of different species has identified increased production from cows when offered legume dominant forages over grass dominant forages (Harris et al., 1998; Woodward et al., 2010). The inconsistency of results in the literature suggests the nutritive value or density of the forage offered, rather than its species diversity, ultimately determines the milk yield response.

In experiments that recorded improvements in milk production (Totty et al., 2013; Woodward et al., 2013), the results were attributed to increased voluntary intake, greater digestibility, and lower fiber content of legume- or forb-containing pastures. Consistent with this, in our experiments, the RCPM forage treatment and the white clover and plantain components of the SAM treatments had a greater IVDMD or a lower

Table 8. Selection differentials for perennial ryegrass, white clover, plantain, CP, NDF, and ADF in each of the 3 experiments $^{1}$

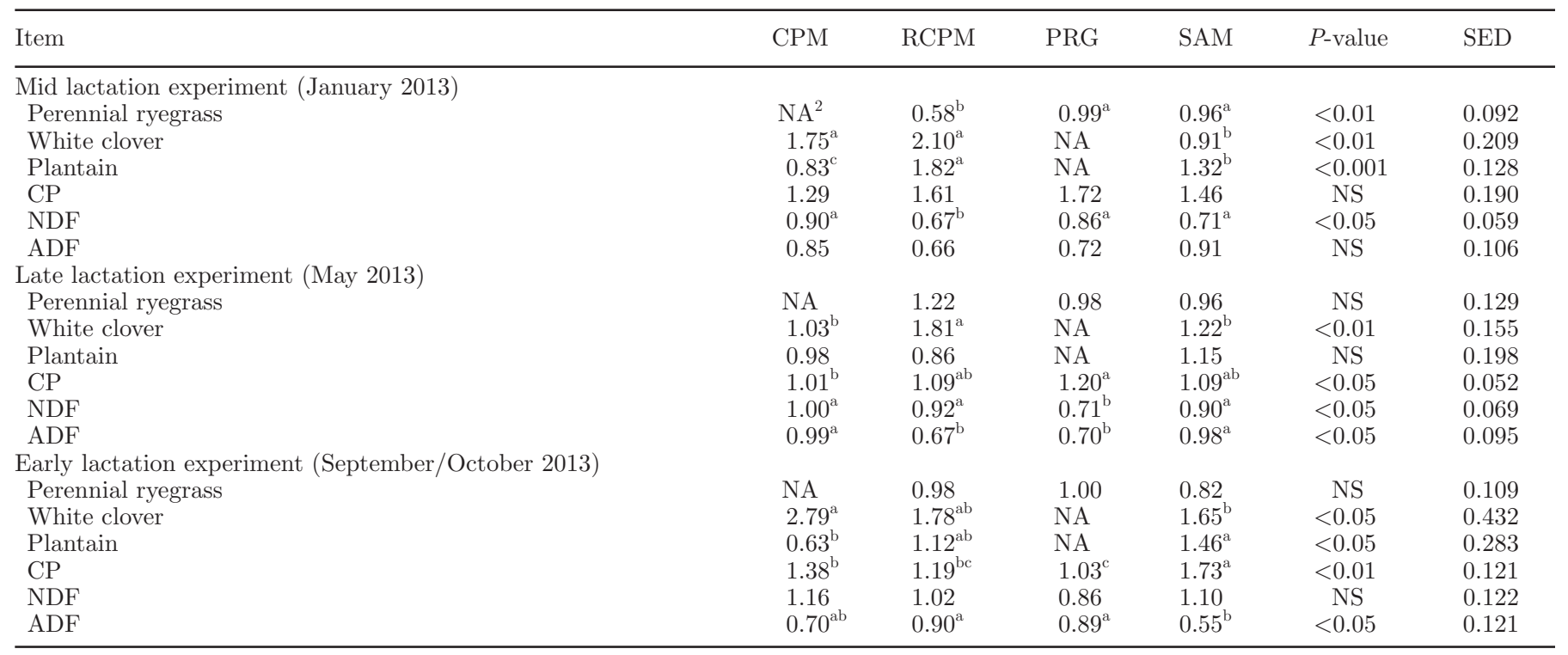

\footnotetext{
${ }^{\mathrm{a}-\mathrm{c}}$ Means within a row with different superscripts differ $(P<0.05)$.

${ }^{1} \mathrm{CPM}=$ white clover and plantain mixture; PRG = perennial ryegrass; RCPM = perennial ryegrass, white clover, and plantain mixture; SAM $=$ spatially adjacent monocultures of perennial ryegrass, white clover, and plantain.

${ }^{2} \mathrm{NA}=$ not applicable.

$\mathrm{NS}=P>0.05 ;{ }^{*} P<0.05 ;{ }^{* *} P<0.01 ;{ }^{* *} P<0.001$.
} 
NDF than the PRG forage treatment. Interestingly, the CPM treatment also had a lower NDF content than the PRG treatment, but this treatment did not have the increased milk production shown in the RCPM and SAM treatments. The CPM treatment had lower pregrazing biomass, which meant cows would have been less efficient in grazing this treatment compared with the other treatments.

The arrangement of the species in the monocultures in the SAM treatment allowed the cows to selectively graze the best possible diet (Penning et al., 1995; Rook et al., 2002). The calculated selection differentials indicated cows grazing the SAM had the greatest selection for $\mathrm{CP}$ during the early lactation experiment and the greatest selection against NDF and ADF, respectively, in the mid and late lactation experiments. This may be the reason other investigators (Champion et al., 2004; Molle et al., 2007) have observed increased milk production from dairy sheep grazing grass-legume SAM compared with grass legume mixtures. Champion et al. (2004) noted that sheep grazing perennial ryegrasswhite clover SAM were effectively able to select a diet of $62 \%$ white clover, which is close to the $3: 7$ ratio of grass to legume that allows for optimal rumen microbial activity as identified in vitro by Merry et al. (2002).

At no time during the experiments were the measured blood metabolite concentrations for BHB or fatty acids at thresholds defined by Duffield et al. (2009) and Ospina et al. (2010) indicating cows were in energy deficit. The measurements undertaken in our experiments indicated the RCPM and SAM treatments would potentially continue to support increased levels of milk production if grazing pressure was increased. As grazing pressure is a product of stocking rate and increasing stocking rate is linked to home-grown forage consumption, a key determinant of the success of pasture-based dairy businesses (Mitchell, 1998; van Bysterveldt, 2005), confirming this hypothesis will be important before the widespread adoption of forage systems based on either RCPM or SAM treatments.

Whereas cows in the RCPM and SAM treatments exhibited a selection preference for $\mathrm{CP}$ and against $\mathrm{NDF}$ and ADF in the grazed forage, the measured postgrazing $\mathrm{CP}$ was still greater and $\mathrm{NDF}$ and $\mathrm{ADF}$ contents of these treatments were lower than in the PRG treatment. These results can be attributed to the white clover and plantain content of the SAM and RCPM pastures. The decline in $\mathrm{CP}$ and increased fiber content will be a potential challenge in maintaining the observed improvements in milk production with greater grazing pressure and reduced forage allowances. Furthermore, the BUN concentrations from cows grazing the RCPM in the mid lactation experiments and for both SAM and RCPM treatments in the late lacta- tion experiment were at levels, defined by Roseler et al. (1993) and Baker et al. (1995), indicating a dietary protein deficit. However, this result needs to be considered in the context of the $\mathrm{N}$ fertilizer management in our experiments, which was set at $120 \mathrm{~kg}$ of $\mathrm{N} / \mathrm{ha}$, evenly split over 3 applications per annum. Typical N fertilizer application rates to dairy pastures in southern Australia are in the order of $220 \mathrm{~kg}$ of N/yr (Gourley et al., 2007). For our experiments, the lower N application rates were used to ensure a high density of white clover in both the RCPM and CPM treatments, as high levels of synthetic $\mathrm{N}$ application have been associated with a decline in forage legume species in dairy pastures (Feyter et al., 1985; Bolland and Guthridge, 2007).

Our experiments identified that pasture mixtures of a perennial ryegrass, white clover, and plantain or spatially adjacent monocultures of these species can support an increase in cow milk volume and milk component production during early lactation and increase cow milk component production during mid lactation (volume and milk components) beyond that achieved from ryegrass monocultures during early and mid lactation, with no negative consequences from grazing such mixtures during late lactation. Hence, both mixtures and spatially adjacent monocultures present an opportunity to produce more milk from forage in pasture-based dairy systems. Future research should focus on the agronomic and grazing management of these pasture types to ensure the potential benefits identified in this experiment will translate to the whole farm system.

\section{ACKNOWLEDGMENTS}

This work was undertaken as part of the "More Milk From Forages" project with funding from Dairy Australia Ltd. (Melbourne). The authors gratefully acknowledge the statistical advice from Ross Corkrey (University of Tasmania, Hobart), the advice from John Roche (DairyNZ, New Zealand), and technical support of Philip Murphy, Susan Walker, Karen Christie, Lesley Irvine, Alison Hall, and Peter Chamberlain (Tasmanian Institute of Agriculture, Burnie) as well as the farm staff at the Tasmanian Dairy Research Facility (Elliot, Tasmania).

\section{REFERENCES}

AOAC. 1990. Fiber (acid detergent) and lignin in animal feed. Official Methods of Analysis. 15th ed. Association of Official Analytical Chemists, Gaithersburg, MD.

AOAC International. 1997. Official method 973.18. Fiber (acid detergent) and lignin in animal feed. Pages 28-29 in Official Methods of Analysis of AOAC International. AOAC International, Arlington, VA. 
AOAC International. 2005. Official method 942.05. Ash of animal feed. Page 8 in Official Methods of Analysis of AOAC International. AOAC International, Gaithersburg, MD.

Baker, L. D., J. D. Ferguson, and W. Chalupa. 1995. Responses in urea and true protein of milk to different protein feeding schemes for dairy cows. J. Dairy Sci. 78:2424-2434

Barry, T. N. 1998. The feeding value of chicory (Cichorium intybus) for ruminant livestock. J. Agric. Sci. 131:251-257.

Bolland, M. D. A., and I. F. Guthridge. 2007. Responses of intensively grazed dairy pastures to applications of fertiliser nitrogen in southwestern Australia. Aust. J. Exp. Agric. 47:927-941.

Brown, H. E., D. J. Moot, and K. M. Pollock. 2005. Herbage production, persistence, nutritive characteristics and water use of perennial forages grown over 6 years on a Wakanui silt loam. N. Z. J. Agric. Res. 48:423-439.

Campling, R. C. 1984 Lucerne, red clover, and other forage legumes: Feeding value and animal production Pages 140-146 in Forage Legumes. Occasional Symposium No. 16. D. J. Thomson, ed. British Grassland Society, Hurley, UK.

Champion, R. A., R. J. Orr, P. D. Penning, and S. M. Rutter. 2004. The effect of the spatial scale of heterogeneity of two herbage species on the grazing behaviour of lactating sheep. Appl. Anim. Behav. Sci. 88:61-76.

Conrad, H. R., R. W. Van Keuren, and B. A. Dehority. 1982 Topgrazing high-protein forages with lactating cows. Pages 690-692 in Proceedings of the 14th International Grasslands Congress. Lexington, Kentucky. Westview Press, Boulder, CO.

CSIRO. 2007 Nutrient Requirements of Domesticated Ruminants. M. Freer, H. Dove, and J.V. Nolan, ed. CSIRO Publishing, Melbourne, Australia.

Derrick, R. W., G. Moseley, and D. Wilman. 1993. Intake, by sheep, and digestibility of chickweed, dandelion, dock, ribwort and spurrey, compared with perennial ryegrass. J. Agric. Sci. 120:51-61.

Doyle, P. T., C. R. Stockdale, A. W. Lawson, and D. C. Cohen. 2000 Pastures for Dairy Production in Victoria. Department of Natural Resources and Environment, Kyabram, Victoria.

Duffield, T. F., K. D. Lissemore, B. W. McBride, and K. E. Leslie. 2009. Impact of hyperketonemia in early lactation dairy cows on health and production. J. Dairy Sci. 92:571-580.

Feyter, C., M. B. Oconnor, and B. Addison. 1985. Effects of rates and times of nitrogen application on the production and composition of dairy pastures in Waikato district, New Zealand. N. Z. J. Exp. Agric. 13:247-252.

Foster, L. 1988. Herbs in pastures-Development and Research in Britain, 1850-1984. Biol. Agric. Hortic. 5:97-133.

Frame, J., J. F. L. Charlton, and A. S. Laidlaw. 1998 Temperate Forage Legumes. CAB International, New York, NY.

Frame, J., and S. Laidlaw. 2005 Prospects for temperate forage legumes. Pages 1-28 in Grasslands: Developments, Opportunities, Perspectives. S. G. Reynolds and J. Frame, ed. Science Publishers, Enfield, NH.

Goering, H. K., and P. J. Van Soest. 1970. Forage fiber analyses (apparatus, reagents, procedures, and some applications). Pages 13-14 in ARS/USDA Handbook No. 379. USDA, Washington, DC.

Gourley, C. J. P., J. M. Powell, W. J. Dougherty, and D. M. Weaver. 2007. Nutrient budgeting as an approach to improving nutrient management on Australian dairy farms. Aust. J. Exp. Agric. 47:1064-1074.

Hall, M. B., W. H. Hoover, J. P. Jennings, and T. K. M. Webster. 1999. A method for partitioning neutral detergent-soluble carbohydrates. J. Sci. Food Agric. 79:2079-2086.

Harris, S. L., M. J. Auldist, D. A. Clark, and E. B. Jansen. 1998. Effects of white clover content in the diet on herbage intake, milk production and milk composition of New Zealand dairy cows housed indoors. J. Dairy Res. 65:389-400.

Holmes, C. W. 2007. The challenge for pasture-based dairying: Learning from the unrecognised systems experts, good farmers. Pages 11-34 in Dairy Science 2007, Meeting the Challenges for PastureBased Dairying, Proceedings of the 3rd Dairy Science Symposium. D. F. Chapman, D. A. Clark, K. L. Macmillan, and D. P. Nation, ed. University of Melbourne, Melbourne, Australia.
Isbell, R. F. 2002. The Australian Soil Classification. CSIRO Publishing, Collingwood, Australia.

Irvine, L. D., M. J. Freeman, and R. P. Rawnsley. 2010. The effect of grazing residual control methods on cow intake and milk production in late spring. Pages 195-198 in Meeting the Challenges of Pasture-Based Dairying, Proceedings of the 4th Australasian Dairy Science Symposium. G. R. Edwards and R. H. Bryant, ed. Lincoln University, Christchurch, New Zealand.

Jacobs, J. L., F. R. McKenzie, and G. N. Ward. 1999. Changes in the botanical composition and nutritive characteristics of pasture, and nutrient selection by dairy cows grazing rainfed pastures in western Victoria. Aust. J. Exp. Agric. 39:419-428.

Kusmartono, T. N. Barry, P. R. Wilson, P. D. Kemp, and K. J. Stafford. 1996. Effects of grazing chicory (Cichorium intybus) and perennial ryegrass (Lolium perenne) white clover (Trifolium repens) pasture upon the growth and voluntary feed intake of red and hybrid deer during lactation and post-weaning growth. J. Agric. Sci. 127:387-401.

Labreveux, M., M. A. Sanderson, and M. H. Hall. 2006. Forage chicory and plantain: Nutritive value of herbage at variable grazing frequencies and intensities. Agron. J. 98:231-237.

Merry, R. J., D. K. Leemans, and D. R. Davies. 2002 Improving the efficiency of silage- $\mathrm{N}$ utilisation in the rumen through the use of perennial ryegrasses high in water-soluble carbohydrate content. Pages 374-375 in Proceedings of the XIII International Silage Conference SAC. Auchincruive, Ayr, Scotland.

Mitchell, G. 1998 Profitable Pasture Use: A Key to Cost-Efficient Dairying in South Australia. Primary Industries and Resources South Australia, Adelaide, Australia.

Molle, G., A. Cabiddu, and M. Decandia. 2007. Re-visiting the nutrition of dairy sheep grazing mediterranean pastures. Ital. J. Anim. Sci. 6:235-243.

Muir, S. K., G. N. Ward, and J. L. Jacobs. 2014. Milk production and composition of mid-lactation cows consuming perennial ryegrassand chicory-based diets. J. Dairy Sci. 97:1005-1015.

Neal, J. S., W. J. Fulkerson, and B. G. Sutton. 2011. Differences in water-use efficiency among perennial forages used by the dairy industry under optimum and deficit irrigation. Irrig. Sci. 29:213-232.

Ospina, P. A., D. V. Nydam, T. Stokol, and T. R. Overton. 2010. Associations of elevated nonesterified fatty acids and beta-hydroxybutyrate concentrations with early lactation reproductive performance and milk production in transition dairy cattle in the northeastern United States. J. Dairy Sci. 93:1596-1603.

Pembleton, K. G., R. P. Rawnsley, and L. L. Burkitt. 2013. Environmental influences on optimum nitrogen fertiliser rates for temperate dairy pastures. Eur. J. Agron. 45:132-141.

Penning, P. D., A. J. Parsons, R. J. Orr, A. Harvey, and R. A. Champion. 1995. Intake and behaviour responses by sheep when grazing monocultures of grass or white clover. Appl. Anim. Behav. Sci. 45:63-78

Picasso, V. D., E. C. Brummer, M. Liebman, P. M. Dixon, and B. J. Wilsey. 2011. Diverse perennial crop mixtures sustain higher productivity over time based on ecological complementarity. Renew. Agric. Food Syst. 26:317-327.

Pirhofer-Walzl, K., K. Soegaard, H. Hogh-Jensen, J. Eriksen, M. A. Sanderson, J. Rasmussen, and J. Rasmussen. 2011. Forage herbs improve mineral composition of grassland herbage. Grass Forage Sci. 66:415-423.

Rawnsley, R. P., B. R. Cullen, L. R. Turner, D. J. Donaghy, M. Freeman, and K. M. Christie. 2009. Potential of deficit irrigation to increase marginal irrigation response of perennial ryegrass ( $\mathrm{Lo}$ lium perenne L.) on Tasmanian dairy farms. Crop Pasture Sci. 60:1156-1164.

Rawnsley, R. P., D. J. Donaghy, and D. R. Stevens. 2007. What is limiting production and consumption of perennial ryegrass in temperate dairy regions of Australia and New Zealand? Pages 256-276 in Dairy Science 2007, Meeting the Challenges for Pasture-Based Dairying, Proceedings of the 3rd Dairy Science Symposium. D. F. Chapman, D. A. Clark, K. L. Macmillan, and D. P. Nation, ed. The University of Melbourne, Melbourne, Australia. 
Rook, J., A. Harvey, A. J. Parsons, P. D. Penning, and R. J. Orr. 2002. Effect of long term changes in relative resource availability on dietary preference of grazing sheep for perennial ryegrass and white clover. Grass Forage Sci. 57:54-60.

Roseler, D. K., J. D. Ferguson, C. J. Sniffen, and J. Herrema. 1993. Dietary-Protein degradability effects on plasma and milk urea nitrogen and milk non protein nitrogen in Holstein cows. J. Dairy Sci. 76:525-534.

Sanderson, M. A., K. J. Soder, L. D. Muller, K. D. Klement, R. H Skinner, and S. C. Goslee. 2005. Forage mixture productivity and botanical composition in pastures grazed by dairy cattle. Agron. J. 97:1465-1471.

Soder, K. J., M. A. Sanderson, J. L. Stack, and L. D. Muller. 2006. Intake and performance of lactating cows grazing diverse forage mixtures. J. Dairy Sci. 89:2158-2167.

Soil Survey Staff. 1990 Keys to Soil Taxonomy. 4th ed. Soil Management Support Service Technical Monograph No. 19. Soil Survey Staff, Blacksburg, VA.

Stewart, A. V. 1996 Plantain (Plantago lanceolata) -A potential pasture species. Proc. N. Z. N. Z. Grass. Assoc. 58:77-86.

Sun, X. Z., S. O. Hoskin, G. G. Zhang, G. Molano, S. Muetzel, C. S. Pinares-Patino, H. Clark, and D. Pacheco. 2012. Sheep fed forage chicory (Cichorium intybus) or perennial ryegrass (Lolium perenne) have similar methane emissions. Anim. Feed Sci. Technol. $172: 217-225$.

Thiex, N. J., S. Anderson, and B. Gildemeister. 2003. Crude fat, diethyl ether extraction, in feed, cereal grain, and forage (Randall/ Soxtec/submersion method): Collaborative study. J. AOAC Int. $86: 888-898$.
Thiex, N. J., H. Manson, S. Anderson, and J. A. Persson. 2002. Determination of crude protein in animal feed, forage, grain, and oilseeds by using block digestion with a copper catalyst and steam distillation into boric acid: Collaborative study. J. AOAC Int. 85:309-317.

Thomson, D. J., D. E. Beever, M. J. Haines, S. B. Cammell, R. T. Evans, M. S. Dhanoa, and A. R. Austin. 1985. Yield and composition of milk from Friesian cows grazing either perennial ryegrass or white clover in early lactation. J. Dairy Res. 52:17-31.

Totty, V. K., S. L. Greenwood, R. H. Bryant, and G. R. Edwards. 2013. Nitrogen partitioning and milk production of dairy cows grazing simple and diverse pastures. J. Dairy Sci. 96:141-149.

van Bysterveldt, A. 2005. Lincoln University dairy farm, now a cropping farm? In South Island Dairy Event (SIDE). South Island Dairy Event (SIDE), Lincoln University, Lincoln, New Zealand.

van Soest, P. J., J. B. Robertson, and B. A. Lewis. 1991. Methods of dietary fiber, neutral detergent fiber, and nonstarch polysaccharides in relation to animal nutrition. J. Dairy Sci. 74:3583-3597.

Woodward, S. L., G. C. Roach, K. A. Macdonald, and J. C. Siemelink. 2008 Forage mixed ration dairy farming - The pros and cons. Proc. N. Z. Grassl. Assoc. 70:183-188.

Woodward, S. L., G. C. Waghorn, G. C. Attwood, and D. Li. 2010 Ryegrass to lucerne-Effects of dietary change on intake, milk yield and rumen microflora bacteria of dairy cows. Proc. N.Z. Soc. Anim. Prod. 70:57-61.

Woodward, S. L., C. D. Waugh, C. G. Roach, D. Fynn, and J. Phillips. 2013 Are diverse species mixtures better pastures for dairy farming? Proc. N. Z. Grassl. Assoc. 75:79-84. 